\title{
Wildfire and abrupt ecosystem disruption on California's Northern Channel Islands at the Ållerød-Younger Dryas boundary (13.0-12.9 ka)
}

\author{
D.J. Kennett ${ }^{a}$, J.P. Kennett ${ }^{b}$, G.J. West ${ }^{c}$, J.M. Erlandson ${ }^{d}$, J.R. Johnson ${ }^{\mathrm{e}}$, I.L. Hendy ${ }^{\mathrm{f}}$, A. West ${ }^{\mathrm{g}}$, \\ B.J. Culleton ${ }^{\text {a }}$, T.L. Jones ${ }^{\mathrm{h}}$, Thomas W. Stafford, Jr. ${ }^{\mathrm{i}}$ \\ a Department of Anthropology, 1218 University of Oregon, Eugene, OR 97403, USA \\ ${ }^{\mathrm{b}}$ Department of Earth Science, Marine Science Institute, University of California, Santa Barbara, CA 93106, USA \\ ${ }^{\mathrm{c}}$ Department of Anthropology, University of California, Davis, CA 95616, USA \\ ${ }^{\mathrm{d}}$ Department of Anthropology, Museum of Natural and Cultural History, University of Oregon, Eugene, OR 97403, USA \\ e Santa Barbara Museum of Natural History, 2559 Puesta del Sol, Santa Barbara, CA 93105, USA \\ ${ }^{\mathrm{f}}$ Department of Geological Sciences, University of Michigan, Ann Arbor, MI, USA \\ ${ }^{g}$ GeoScience Consulting, Dewey, AZ 86327, USA \\ ${ }^{\mathrm{h}}$ Department of Social Sciences, California Polytechnic State University, San Luis Obispo, CA 93407, USA \\ ${ }^{\mathrm{i}}$ Stafford Research Laboratories, Inc., 200 Acadia Avenue, Lafayette, CO 80026, USA
}

\begin{abstract}
A B S T R A C T
Sedimentary records from California's Northern Channel Islands and the adjacent Santa Barbara Basin (SBB) indicate intense regional biomass burning (wildfire) at the Ållerød-Younger Dryas boundary $(\sim 13.0-12.9 \mathrm{ka})$ (All age ranges in this paper are expressed in thousands of calendar years before present [ka]. Radiocarbon ages will be identified and clearly marked “14C years".). Multiproxy records in SBB Ocean Drilling Project (ODP) Site 893 indicate that these wildfires coincided with the onset of regional cooling and an abrupt vegetational shift from closed montane forest to more open habitats. Abrupt ecosystem disruption is evident on the Northern Channel Islands at the Ållerød-Younger Dryas boundary with the onset of biomass burning and resulting mass sediment wasting of the landscape. These wildfires coincide with the extinction of Mammuthus exilis [pygmy mammoth]. The earliest evidence for human presence on these islands at $13.1-12.9 \mathrm{ka}\left(\sim 11,000-10,900{ }^{14} \mathrm{C}\right.$ years $)$ is followed by an apparent $600-$ 800 year gap in the archaeological record, which is followed by indications of a larger-scale colonization after $12.2 \mathrm{ka}$. Although a number of processes could have contributed to a post $18 \mathrm{ka}$ decline in $M$. exilis populations (e.g., reduction of habitat due to sea-level rise and human exploitation of limited insular populations), we argue that the ultimate demise of $M$. exilis was more likely a result of continental scale ecosystem disruption that registered across North America at the onset of the Younger Dryas cooling episode, contemporaneous with the extinction of other megafaunal taxa. Evidence for ecosystem disruption at 13-12.9 ka on these offshore islands is consistent with the Younger Dryas boundary cosmic impact hypothesis [Firestone, R.B., West, A., Kennett, J.P., Becker, L., Bunch, T.E., Revay, Z.S., Schultz, P.H., Belgya, T., Kennett, D.J., Erlandson, J.M., Dickenson, O.J., Goodyear, A.A., Harris, R.S., Howard, G.A., Kloosterman, J.B., Lechler, P., Mayewski, P.A., Montgomery, J., Poreda, R., Darrah, T., Que Hee, S.S., Smith, A.R., Stich, A., Topping, W., Wittke, J.H. Wolbach, W.S., 2007. Evidence for an extraterrestrial impact 12,900 years ago that contributed to the megafaunal extinctions and Younger Dryas cooling. Proceedings of the National Academy of Sciences 104, 16016-16021.].
\end{abstract}

\section{Introduction}

Abrupt and massive environmental and biotic changes are evident at the Ållerød-Younger Dryas Boundary (YDB, 13.0-12.9 ka) in the archaeological and paleontological records of North America. It appears that at least 16 of 35 extinct Late Pleistocene animal genera have abrupt, terminal occurrences at, or close to, this boundary (Firestone et al., 2007; Grayson, 2007; Haynes, 2008). The remaining genera are rare in the Pleistocene record and the available chronological information is generally insufficient to evaluate their extinction histories. This is also the case for 19 extinct Late Pleistocene bird genera (Grayson, 2007). Grayson and Meltzer (2002) hypothesized that these extinctions were gradual during the Late Pleistocene and that processes causing the massive extinction 
were temporally and regionally complex and related to the changing environmental conditions associated with deglaciation. Animal extinction histories should be complex during such significant environmental shifts, but the abrupt extinction of significant numbers of genera/species at $\sim 13-12.9$ ka occurred during a time of more gradual ecosystem processes associated with the last deglacial episode. A continental scale AMS ${ }^{14} \mathrm{C}$ dating campaign is required to test the hypothesis that posits an abrupt environmental and biotic event. Relatively comprehensive extra-regional data are in strong support of an abrupt extinction of several Rancholabrean mammalian taxa including Equus [Horse], Camelops [Camel], and Mammuthus [Mammoth] (Haynes, 2008), with the best dataset from Mammuthus indicating that this genus abruptly disappeared over much of the continent at $\sim 12.9 \mathrm{ka}$ (Haynes, 2008). By this time most of North American megafauna were extinct, with Bison spp. a rare survivor that experienced a significant population bottleneck at $\sim 12.9 \mathrm{ka}$ (Drummond et al., 2005). This appears to have stimulated genetic change that ultimately led to the appearance of the modern Bison [Bison bison] during the Holocene (McDonald, 1981). The abrupt termination of multiple genera and the bottleneck in bison populations at or close to 12.9 ka demands explanation.

The rapid extinction of many Rancholabrean animals is closely timed to the Clovis cultural assemblage that abruptly appeared and disappeared across North America between 13.1 and $12.9 \mathrm{ka}$ (Waters and Stafford, 2007) and immediately preceded the Younger Dryas (YD) cooling (Broecker, 2006). Our opinion is that Martin's (1967, 2005) long-standing hypothesis that human hunting was responsible for this extinction (overkill) event is not supported by the available data. The reasons are that there is a near-absence of kill sites for many of these genera, including camels and sloths (Grayson and Meltzer, 2002; Grayson, 2007), the event was rapid, encompassed numerous animal taxa, and had a large geographic extent. In addition, increasing evidence for pre-Clovis human occupations negates an explosive occurrence of people rapidly expanding throughout the Americas (Dillehay, 1989, 1997; Waters and Stafford, 2007; Gilbert et al., 2008). The rapid onset of YD cooling is recorded throughout the Northern Hemisphere, in equatorial climate records (Haug et al., 2001; Hendy et al., 2002; Yancheva et al., 2007), and provides another potential explanation for the abrupt extinction event. The timing of YD cooling is out of phase with the chronology of Milankovitch forcing mechanisms, but its severity and rate of onset is comparable to many such cooling events during the Late Quaternary (Hendy et al., 2002) and hence by itself does not provide an adequate explanation for ecosystem disruption and massive extinction. More complex ecological explanations involving a combination of climate change and human predation are the most viable (Barnosky et al., 2004) in the absence of alternative mechanisms, however, based on 97 geoarchaeological sequences across North America, Haynes (2008) argues for a dramatic environmental event at $\sim 12.9 \mathrm{ka}\left(10,900{ }^{14} \mathrm{C}\right.$ years). He argued that the base on a physically distinctive YD black layer at 70 of these localities dates to $\sim 12.9 \mathrm{ka}$ and serves as a stratigraphic marker horizon (Fig. 1) - a thin stratum where Clovis artifacts and select Rancholabrean fauna occur below, but never within or above this unique bed (Haynes, 2005, 2008; see also Firestone et al., 2007).

Magnetic microspherules are concentrated at the base of the best dated of these distinctive black layers at Murray Springs, AZ (Haynes, 2008) and in association with an assemblage of numerous other exotic materials identified in many other terminal Clovis-age deposits (Firestone et al., 2007). Many of these exotic materials are found in sediments associated with documented extraterrestrial impact events (e.g., Cretaceous-Tertiary [K/T] boundary [Köeberl, 2007]; Tunguska [Longo et al., 1994]). Although much remains to be learned about this boundary layer, the co-occurrence of these exotic materials forms the basis of the Younger Dryas Boundary (YDB) cosmic impact hypothesis (Firestone et al., 2007). Large cosmic impacts can have major effects on Earth systems and are known to trigger abrupt climatic shifts, widespread biomass burning, and animal extinctions (Alvarez et al., 1980; Wolbach et al., 1985). The recognition of mass extinction at the $\mathrm{K} / \mathrm{T}$ boundary attributed to a major cosmic impact, along with the presence of a significant number of similar cosmic impact markers identified at the YDB, provide an empirical basis for hypothesizing that North American animal extinctions at the end of the Pleistocene had a similar origin. These extinctions may have been caused, at least in part, by the direct effects of an cosmic impact (shockwave and heat) and subsequent major and cascading ecological changes (e.g., regional wildfires, climate change, vegetation disturbance and shifts). Much of the existing archaeological, paleontological, and paleoenvironmental data in North America are not adequate to test the YDB cosmic impact hypothesis due to sparse geographic occurrences and insufficient chronological resolution in available records. The apparent suddenness of the event that occurred at the onset of the YD requires investigations of very high chronological resolution to test the hypothesis. A first step in evaluating the YDB cosmic impact hypothesis is the further analysis of existing stratigraphic and chronological datasets, removing erroneous radiocarbon dates that have large error margins (Spriggs, 1989; also see Pettitt et al., 2003; Waters and Stafford, 2007; contra the approach of Buchanan et al. 2008) or other problems (e.g., the 'old wood effect'; Schiffer, 1986; Kennett et al., 2002). Unless the objects of interest are dated directly (e.g., Pleistocene animal bones, dung, or other biological remains) stratigraphic context is essential with all sites with questionable radiocarbon dates or associations removed until confirmed with modern techniques. Calibration with careful attention to ${ }^{14} \mathrm{C}$ reservoir problems is essential (Ingram and Southon, 1996; Kennett et al., 1997), as is careful consideration of radiocarbon production plateaus and uncertainties in the calibration curve known to exist during this interval (Muscheler et al., 2008). The same rigorous criteria expected for defining pre-Clovis occupations are now required for all terminal Pleistocene stratigraphic sequences.

It is in this context that we present evidence for the co-occurrence of massive wildfire, abrupt vegetation change, Mammuthus exilis extinction and disruption in human use of California's Channel Islands at $\sim 13-12.9 \mathrm{ka}$. These islands were never connected to the mainland during the Quaternary and thus provide a unique and detailed record of Proboscidean colonization, biogeography, dwarfism, and extinction in an insular maritime environment (Agenbroad, 2002a, 2005). They also provide a long and well-preserved sequence of human occupation spanning the last 13,000 years (Erlandson et al., 1996, in press; Johnson et al., 2002; Kennett, 2005; Rick et al., 2005). These records are coupled with high-resolution climate and environmental records from the adjacent Santa Barbara Basin (Kennett et al., 1995, 2007; Heusser and Sirocko, 1997; Kennett and Kennett, 2000; Hendy et al., 2002, 2004). High quality SBB records result from a combination of rapid sedimentation rates, general lack of bioturbation, a relatively continuous abundance of climatic/environmental proxies and proximity to continental influences. The paleontological, archaeological, and paleoenvironmental records on these islands provide a unique opportunity to examine $M$. exilis extinction in the context of climatically induced environmental change and the arrival of humans on these islands. We now turn to the existing Late Quaternary paleoenvironmental sequences for the region and the archaeological and paleontological records from the Northern Channel Islands. We then examine the evidence for regional wildfires at 13-12.9 ka and discuss this within the context of existing records and the YDB extraterrestrial impact hypothesis. 


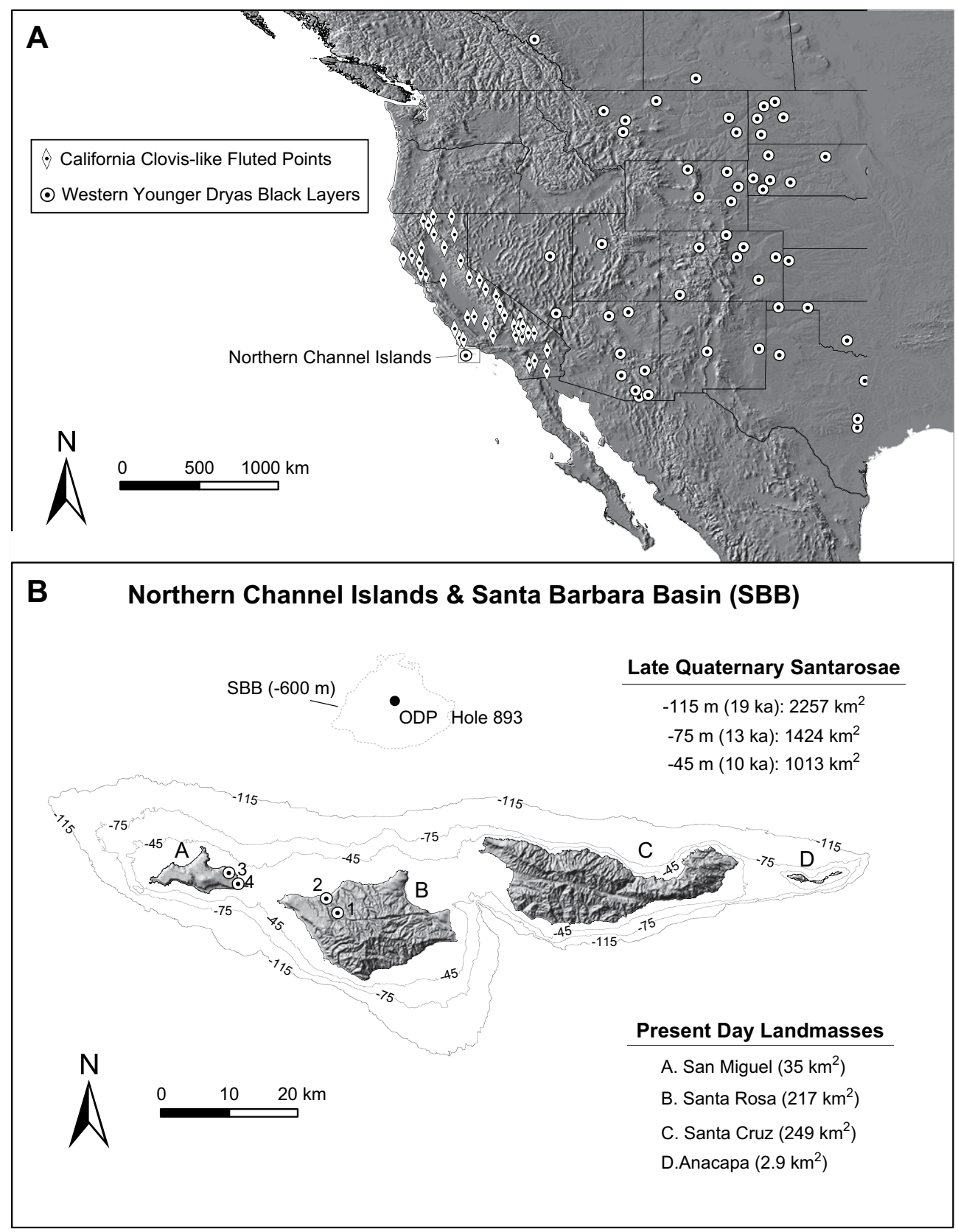

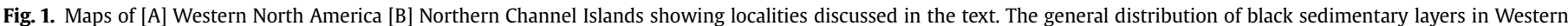

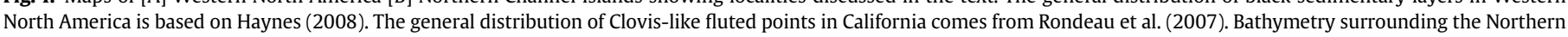

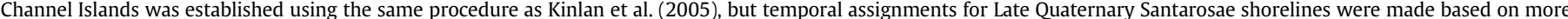

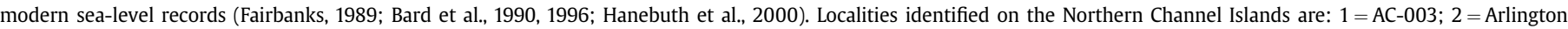
human locality [CA-SRI-173]; 3 = Daisy Cave [CA-SMI-261]; and 4 = Cardwell Bluffs (maps by Jacob Bartruff).

\section{Late Quaternary paleoenvironmental change}

High-resolution Late Pleistocene environmental sequences are limited on the Northern Channel Islands, but the adjacent Santa Barbara Basin (SBB) offers extraordinarily sensitive records of global climate change and associated regional environmental responses on interannual through glacial/interglacial timescales (Kennett et al., 1995, 2007; Behl and Kennett, 1996; Heusser and Sirocko, 1997; Heusser, 1998; Cannariato et al., 1999; Hendy and Kennett, 1999; Kennett and Kennett, 2000; Hendy et al., 2002, 2004; Nederbragt and Thurow, 2005; Graham et al., 2007; Sarnthein et al., 2007; Nederbragt et al., 2008). Well-preserved sediments in the center of this basin record climatic variability closely correlated with
Northern Hemisphere and broader climate history as documented in the Greenland ice core (e.g., GISP2 $\delta^{18} \mathrm{O}$; Hendy et al., 2002). Decreased ventilation leading to varved sediments occurs during warm episodes (Bølling [14.7-14.1 ka], Ållerød [14-12.9 ka], and earliest Holocene [11.6-10.5 ka]) while increased ventilation and resulting non-laminated (bioturbated) ocean sediments typify cool intervals (e.g., Last glacial Maximum [LGM; $18 \mathrm{ka}$ ], Older Dryas [14.1-14 ka], Younger Dryas [YD] [12.9-11.6 ka]; Behl and Kennett, 1996). Planktonic foraminiferal $\delta^{18} \mathrm{O}$ values accord well with these glacial-interglacial cycles and also record multiple, abrupt submillennial-scale cool and warm excursions throughout the Late Quaternary (Hendy et al., 2002), often of similar magnitudes or more extreme than the abrupt cooling that marks the onset of the YD. 
The Late Quaternary age model for ODP Site 893 was established based on a new suite of AMS ${ }^{14} \mathrm{C}$ dates (Sarnthein et al., 2007; Fig. 2). Radiocarbon dating was performed on mixed planktonic foraminifera. A regional reservoir correction $(\Delta R)$ of $233 \pm 60$ years has been assumed (Ingram and Southon, 1996). From the $51{ }^{14} \mathrm{C}$ dates between 9.5 and $20 \mathrm{ka}, 36$ dates were averaged, and 12 dates (including, dates within radiocarbon plateaus) were excluded from the age model. The remaining dates were used to generate 21 calibrated calendar year ages (including 11 that represent average dates). Calibrated calendar year ages were obtained using the full probability method of calendar age calibration (Telford et al., 2004). Reservoir-corrected ${ }^{14} \mathrm{C}$ dates younger than $22{ }^{14} \mathrm{C}$ ka were calibrated using CALIB 4.0 (Stuiver et al., 2004) and the ${ }^{14} \mathrm{C}$ calibration dataset MARINE04 (Hughen et al., 2004).

Sedimentary, faunal, and $\delta^{18} \mathrm{O}$ records in SBB generally show cohesive warm-cool-warm cycles during the Ållerød, YD and Early Holocene, respectively (Fig. 3). The Ållerød-YD transition is marked by a sharp change from laminated to bioturbated sediments (Behl and Kennett, 1996) with non-laminated sediments persisting through the YD, estimated to be $\sim 1300$ years in duration based on an AMS ${ }^{14} \mathrm{C}$ chronology, varve counting, and correlation with the GISP2 ice core record (Kennett and Ingram, 1995a,b; Hendy et al., 2002; Nederbragt and Thurow, 2005). Planktonic foraminiferal $\delta^{18} \mathrm{O}$ isotope and faunal assemblages clearly show: 1) Bølling and Ållerød warm episodes (separated by the Older Dryas); 2) the YD cool episode, and 3) the Early Holocene (Hendy et al., 2002). Planktonic foraminiferal $\delta^{18} \mathrm{O}$ records of thermoclinal (Neogloboquadrina pachyderma) and surface (Globigerina bulloides) water forms are consistent with this hypothesis and indicate abrupt cooling at the onset of the YD. The Bølling-Ållerød warm episode registers in both planktonic foraminiferal species. The onset of the YD is represented by a $1 \%$ increase in $\delta^{18} \mathrm{O}$ (Hendy et al., 2002).

Marine faunal assemblages also indicate cooler sea surface temperatures (SST) during the YD. The ratio of sinistral (left coiling) to dextral (right coiling) in N. pachyderma is highly sensitive to SSTs (summarized in Fisler and Hendy, 2008). Sinistral N. pachyderma forms are favored with a poorly developed thermocline (highupwelling) and SST $<10^{\circ} \mathrm{C}$. The high abundance of the dextral

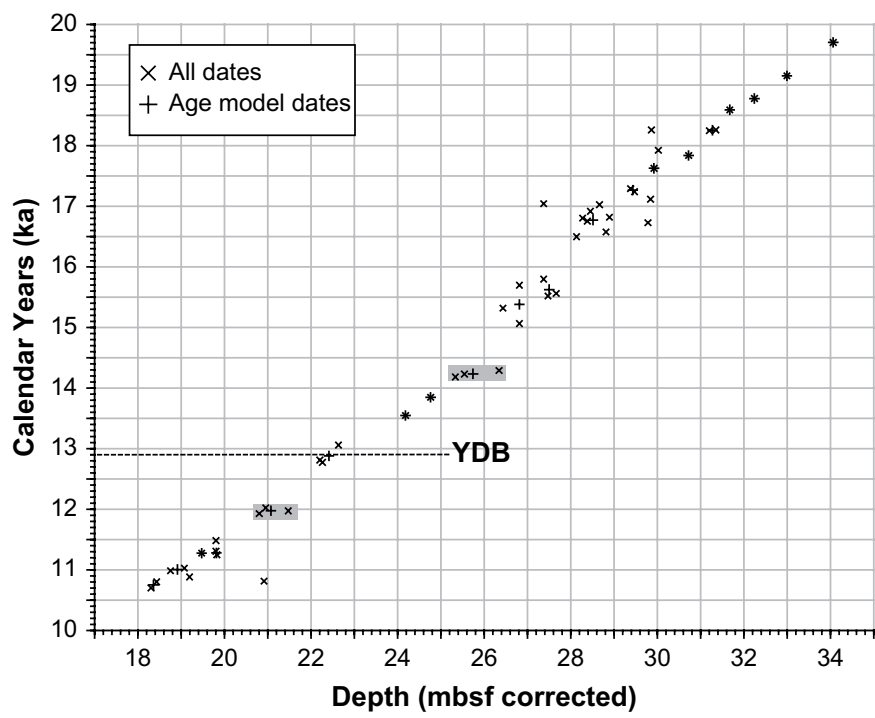

Fig. 2. Age in calendar years BP (ka) versus core depth (corrected cm BSF) for ODP Site 893. Dates were generated using planktonic foraminiferal carbonate ( $\times$ 's) (Roark et al., 2003; Sarnthein et al., 2007). Dates for the age were also generated using the average of multiple dates (crosses). Dates that were used in the linear interpolation of the age model are shown as crosses. Shaded areas highlight globally recognized ${ }^{14} \mathrm{C}$ age plateaus (Sarnthein et al., 2007). coiled morphospecies through much of the Bølling-Ållerød indicates SST $>10^{\circ} \mathrm{C}$, a well-developed thermocline, and intensive upwelling of nutrient-rich water. The Bølling is widely recognized as an interval of unusually high marine productivity in the North Pacific (Hendy et al., 2004). Dextral/sinistral ratios are high in Bølling-Ållerød and Early Holocene assemblages and the YD is marked by an abrupt decrease in this ratio indicating SST $<10^{\circ} \mathrm{C}$. This is consistent with the $\delta^{18} \mathrm{O}$ records for this thermoclinal species indicating cold SSTs during the YD. Planktonic foraminiferal abundance decreased during the YD. Globigerina quinqueloba dominated the assemblage during the YD (40-80\%), while G. bulloides is rare in comparison to Ållerød and Early Holocene assemblages. These species are surface dwellers that thrive in nutrientrich water, however, G. bulloides does not host photosynthetic endosymbionts and consequently has a higher prey requirement (Ortiz et al., 1996). Low foraminiferal abundance and high G. quinqueloba frequencies during the YD indicate a decrease in size and/or frequency of prey perhaps as a result of reduced upwelling (Fisler and Hendy, 2008). Dinoflagellate cyst production increased during the Bølling/Ållerød and diminished during the YD, and is also consistent with reduced upwelling during the cool event (Pospelova et al., 2006). Coccolith assemblages change more gradually across the Ållerød-YD boundary and during the YD they are most similar to the LGM (MIS2). This observation is consistent with other proxies suggesting cool YD SSTs (Nederbragt et al., 2008). An increase in Florisphaera profunda in YD assemblages (much higher than LGM) suggests that coccolithophorid production occurred during seasonal chlorophyll maxima associated with stratification of the water column (Nederbragt et al., 2008, p. 10).

Late Quaternary changes in sea level altered the size and configuration of the Northern Channel Islands between 19.5 and $10 \mathrm{ka}$ (and after), increasing the width of the channel separating these islands from the mainland (Junger and Johnson, 1980). The distribution of highly productive reef habitat and associated kelp forests also changed during this interval (Kinlan et al., 2005), where tectonic influences on eustacy (uplift or subsidence) are relatively minor compared to glacio-eustatic effects during this interval. The Northern Channel Island platform is tilting, subsiding in some locations and uplifting in others (Sorlien, 1994). Fault slip and warping on Santa Rosa and Santa Cruz Islands are similar; both faults are oriented east-west and dipping steeply to the north (Pinter et al., 2001, 2003). Late Quaternary uplift has occurred north of these faults with left slip rates between 0.75 and $1 \mathrm{~mm} /$ year and vertical uplift of $0.1-0.2 \mathrm{~mm} /$ year $(<2 \mathrm{~m}$ in 13,000 years; Pinter et al., 2001, p. 9). During the LGM, sea level was $\sim 120 \mathrm{~m}$ below the current high-level stand (Fairbanks, 1989; Siddall et al., 2003). The four Northern Channel Islands were amalgamated to form one large landmass known as Santarosae (Orr, 1968; Fig. 1b). A land bridge between the mainland and Santarosae did not exist during the Quaternary; however, the distance from the eastern end of the island to the mainland was reduced to $\sim 7 \mathrm{~km}$ at the LGM. Eustatic rises in sea level are not well constrained between 19.5 and $14.5 \mathrm{ka}$, but a gradual rise of $\sim 25 \mathrm{~m}$ is suggested by records in the IndoPacific (Bard et al., 1990; Fig. 3f, Table 1). This would have caused a $\sim 17 \%\left(391 \mathrm{~km}^{2}\right)$ reduction in the size of Santarosae, affecting the coastal lowlands that may have been the most productive habitat for animal populations (Agenbroad, 2002b). A more rapid rise of $15 \mathrm{~m}$ is evident between 14.5 and $13.4 \mathrm{ka}$. Sea level was $\sim 75 \mathrm{~m}$ below the current high stand at the beginning of the YD $(\sim 13-$ $12.9 \mathrm{ka}$ ) and gradual increases ( $\sim 30 \mathrm{~m}$ ) are evident through the YD and Early Holocene $(\sim 12.9-10 \mathrm{ka})$ resulting in another reduction in land area of roughly $16 \%\left(304 \mathrm{~km}^{2}\right)$. In general, these data are evidence for step-like decrease in island size and increased isolation from the mainland superimposed on more gradual trends between 19.5 and $10 \mathrm{ka}$. Potential reef area surrounding the islands expanded between 19.5 and $13.5 \mathrm{ka}$, and contracted gradually 


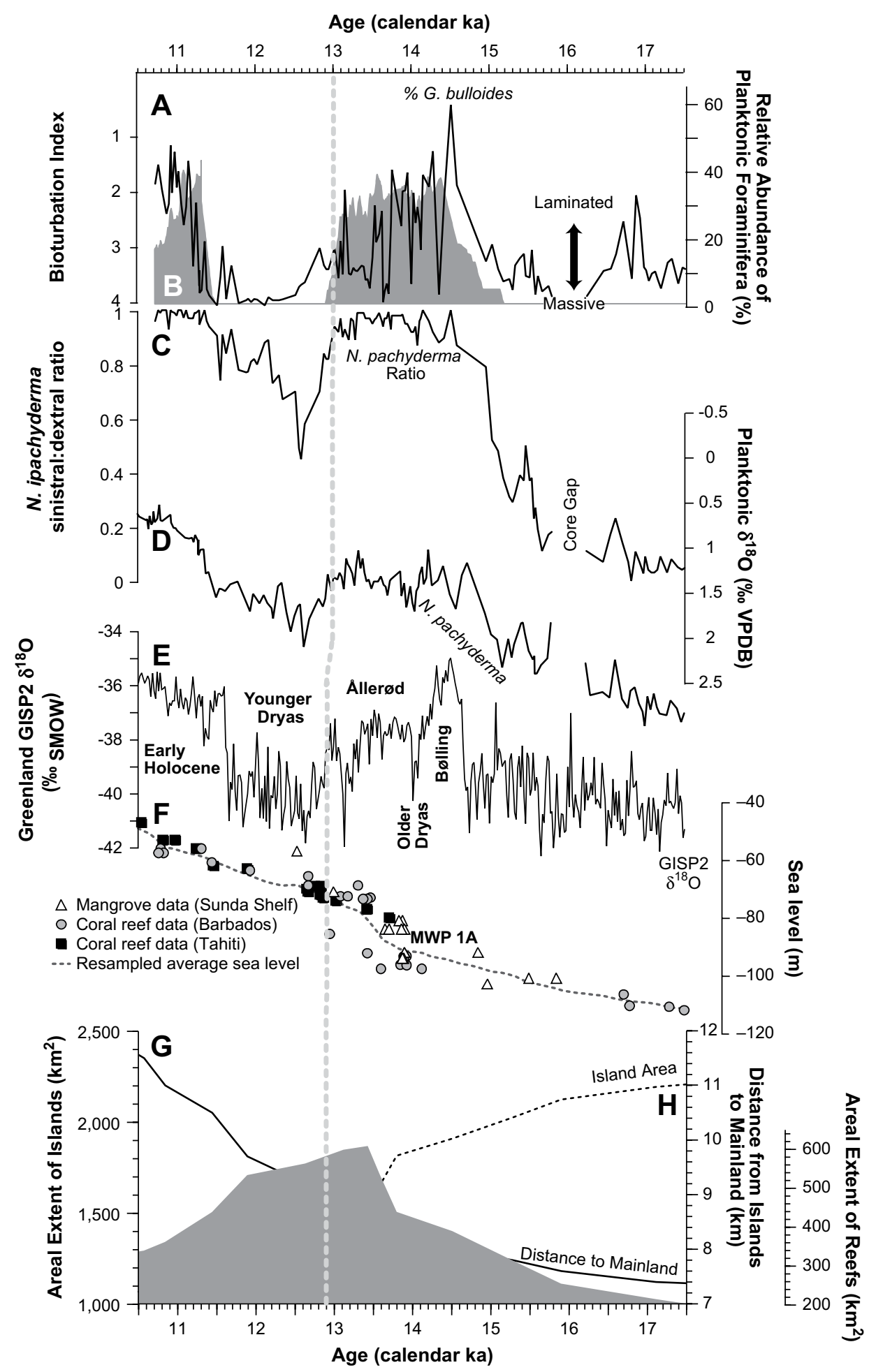

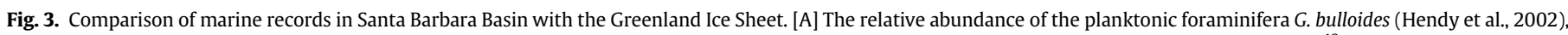

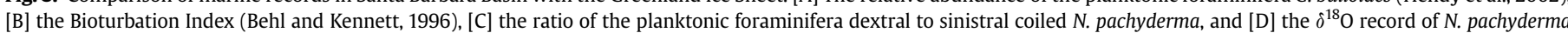

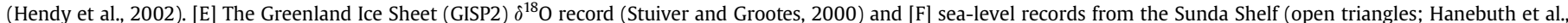

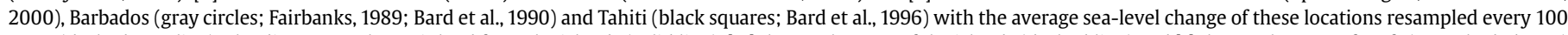

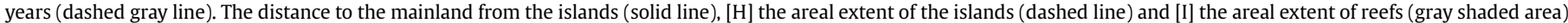
through time. Gray dashed line marks the initiation of the Younger Dryas cooling event in Greenland and Santa Barbara Basin, an event that is considered to be synchronous.

during the late Ållerød and YD (13.5-12 ka). The Northern Channel Islands separated sequentially at $\sim 10.9 \mathrm{ka}$ (Anacapa), $\sim 9.3 \mathrm{ka}$ (Santa Cruz) and $\sim 9$ ka (Santa Rosa-San Miguel); these estimates differ from those of Kinlan et al. (2005; also see Porcasi et al., 1999) due to the use of more recent estimates of sea-level change.

\section{Late Quaternary archaeological records}

A human presence on Santarosae at $\sim 13 \mathrm{ka}$ is indicated by skeletal remains-two partial femora and a patella-at the Arlington Springs site on Santa Rosa Island (CA-SRI-173, Johnson 
Table 1

Estimated areal extent of the Northern Channel Islands during the Late Quaternary and related changes in reef size and distance to mainland.

\begin{tabular}{lllll}
\hline Age $(\mathrm{ka})$ & Bathymetry $(\mathrm{m})$ & Area $\left(\mathrm{km}^{2}\right)$ & Reef area $\left(\mathrm{km}^{2}\right)$ & Mainland $(\mathrm{km})^{\mathrm{a}}$ \\
\hline 9.02 & -30 & 819.13 & 327.33 & 13.00 \\
9.35 & -35 & 893.25 & 313.72 & 12.00 \\
9.72 & -40 & 951.01 & 322.95 & 12.00 \\
10.22 & -45 & 1013.01 & 328.68 & 11.80 \\
10.57 & -50 & 1083.15 & 339.82 & 11.50 \\
10.84 & -55 & 1149.07 & 362.14 & 11.00 \\
11.44 & -60 & 1208.42 & 438.86 & 10.50 \\
11.89 & -65 & 1276.62 & 533.89 & 9.70 \\
12.63 & -70 & 1345.78 & 563.65 & 9.20 \\
13.12 & -75 & 1424.08 & 599.10 & 9.00 \\
13.43 & -80 & 1512.00 & 608.67 & 8.70 \\
13.58 & -85 & 1649.72 & 537.11 & 8.50 \\
13.80 & -90 & 1816.69 & 439.34 & 8.20 \\
14.51 & -95 & 1910.44 & 390.04 & 8.00 \\
15.28 & -100 & 2026.16 & 314.66 & 7.80 \\
15.90 & -105 & 2125.05 & 254.99 & 7.60 \\
17.11 & -110 & 2194.44 & 215.22 & 7.40 \\
18.85 & -115 & 2256.79 & 178.88 & 7.30 \\
19.50 & -120 & 2301.36 & 157.16 & 7.30 \\
\hline
\end{tabular}

${ }^{a}$ Estimated distance from eastern Anacapa to adjacent mainland.

et al., 2002; Fig. 4). Orr (1968) discovered the skeletal remains in 1959 , buried $11 \mathrm{~m}$ below the modern ground surface in a filled arroyo sequence now bisected by the main Arlington Canyon drainage. Several direct dates are available for this skeletal material (Johnson et al., 2002), the most reliable of which is an AMS ${ }^{14} \mathrm{C}$ date on XAD-purified collagen (CAMS-16810, $10,960 \pm 50{ }^{14} \mathrm{C}$ years or 13-12.9 ka; Table 2). A detailed stratigraphic analysis of the sediments surrounding these bones is consistent with this chronology and confirms an age of 13-12.9 ka (Johnson et al., 2002, 2007; Agenbroad et al., 2005). These data are evidence that humans were present on the Northern Channel Islands when contemporary Paleoindian peoples were well distributed throughout North America and used a wide diversity of available resources including the hunting of large game animals with Clovis spear points (Haynes, 2005; Waters and Stafford, 2007). Clovis points and related technology, although found on the adjacent mainland and throughout much of North America (Anderson and Faught, 2000; Erlandson et al., 2007; Rondeau et al., 2007), have not been found on the Northern Channel Islands, but the potential overlap between the most recently dated $M$. exilis skeleton and the Arlington skeletal material suggests that humans may well have encountered these animals at this early date. Regardless, early human presence on these islands provides unequivocal evidence for seaworthy boats and sufficient skill to safely navigate the Santa Barbara Channel (Erlandson et al., 2007).

An apparent 600-800 year gap exists between the age of the Arlington Springs locality and the next evidence for human occupation at $\sim 12.2 \mathrm{ka}$ (Fig. 4). Evidence for human occupation at 12.2 ka occurs at Daisy Cave and Cardwell Bluffs near the east end of modern San Miguel Island. The recently discovered Cardwell Bluffs locality contains several large quarry/workshop sites that have produced hundreds of chipped stone bifaces, including numerous crescents and stemmed projectile points associated with red abalone shells and other well-preserved shellfish remains dating between 12.2 and $11.6 \mathrm{ka}$ (Erlandson et al., in press). The earliest unequivocal evidence for human occupation at Daisy Cave (12.2$11.6 \mathrm{ka}$ ) consists of a handful of Monterey chert and siliceous shale artifacts associated with red abalone and other marine shell fragments from the adjacent rocky intertidal zone (Stratum G; Erlandson et al., 1996; Erlandson, 2007). This short-duration deposit, likely representing a single visit, occurs at the base of a well-stratified sequence that shows consistent and repeated use of the cave starting in the terminal Pleistocene. Early Holocene deposits contain a diverse tool assemblage including projectile points, bone fish gorges, shell beads (Olivella biplicata), sea grass cordage, and chipped stone debris mixed with the remains of fish, sea mammals, birds, and shellfish (Erlandson, 2007; Erlandson et al., 2007). Increased use of Daisy Cave coincides with the occurrence of many other San Miguel and Santa Rosa sites that contain evidence for early maritime adaptations (Rick et al., 2005).

\section{Island mammoth extinction}

Paleoenvironmental trends and the human colonization history provide the ecological context for the extinction of $M$. exilis on Santarosae. Pleistocene faunas on this island were of low diversity compared with the diverse fauna documented at Rancho La Brea just across the Santa Barbara Channel on the California mainland (Marcus and Berger, 1984; Coltrain et al., 2004). Mammoths (Mammuthus columbi) colonized these islands during the Late Quaternary, probably well before $47 \mathrm{ka}$, and perhaps during one of the low sea-level stands prior to this time when the swimming distance was relatively short. A more diminutive Mammuthus species (M. exilis), about the size of a large bison and endemic to

Table 2

Late Quaternary paleontological and archaeological sites from the Northern Channel Islands.

\begin{tabular}{|c|c|c|c|c|c|}
\hline Lab \# & Material dated & Provenance & ${ }^{14} \mathrm{C}$ & $\pm \leftarrow$ & Reference \\
\hline Beta-92053 & Charcoal $\mathrm{w} / M$. exilis & Southwest Coast, Santa Rosa Island & 18,130 & 70 & Agenbroad, 2002b, p. 523 \\
\hline Beta-96610 & Charcoal w/M. exilis & Southeast Coast, Santa Rosa Island & 13,770 & 60 & Agenbroad, 2002b, p. 523 \\
\hline CAMS-71697 & M. exilis (Collagen) ${ }^{\mathrm{b}}$ & Northwest Coast of Santa Rosa Island & 11,030 & 50 & Agenbroad et al., 2005, p. 5 \\
\hline Beta-133594 & Charcoal w/M. exilis & Northwest Coast of Santa Rosa Island & 11,010 & 70 & Agenbroad et al., 2005, p. 5 \\
\hline CAMS-16810 & Human Skeleton ${ }^{\mathrm{b}}$ & SRI-173, Arlington Springs, $11 \mathrm{~m}$ below surface & 10,960 & 80 & Johnson et al., 2002, p. 543 \\
\hline Beta-52360 & Tegula & SMI-261, E-6: Stratum G & 10,600 & 70 & Erlandson et al., 1996 \\
\hline Beta- $14660^{\mathrm{a}}$ & Haliotis rufescens & SMI-261, E-6, Stratum G & 10,700 & 90 & Erlandson et al., 1996 \\
\hline CAMS-33369 & Charred twig & SMI-261, 94-E6, Stratum G & 9580 & 60 & Erlandson et al., 1996 \\
\hline CAMS-14366 & Charred twig & SMI-261, Cave A, $26-30 \mathrm{~cm}$ & 9180 & 60 & Erlandson et al., 1996 \\
\hline CAMS-33375 & Marine Shell & SMI-261, Col. E-6, F-G transition & 9620 & 70 & Erlandson et al., 1996 \\
\hline OS-27943 & Mytilus californianus & SMI-522, Base of midden & 9450 & 70 & Erlandson and Rick, 2002 \\
\hline OS-31684 & Mytilus & SMI-548, Area A: $0-5 \mathrm{~cm}$ & 9070 & 55 & Erlandson et al., 2004 \\
\hline OS-34804 & M. californianus & SMI-604, Probe: 25 & 9440 & 50 & Rick et al., 2001 \\
\hline Beta-145308 & M. californianus & East Locus & 8920 & 90 & Erlandson et al., 2007 \\
\hline OS-44638 & M. californianus & SMI-608 & 9200 & 50 & Erlandson et al., 2005 \\
\hline OS-28282 & M. californianus & SMI-610, Sea Cliff: 0-10 & 9080 & 60 & Erlandson et al., 2007 \\
\hline Beta- $47625^{a}$ & Haliotis rufescens & SRI-6, Component 1 & 8800 & 80 & Erlandson et al., 1999 \\
\hline
\end{tabular}

a Standard radiocarbon $-{ }^{13} \mathrm{C} /{ }^{12} \mathrm{C}$ adjusted.

b XAD-purified collagen. 


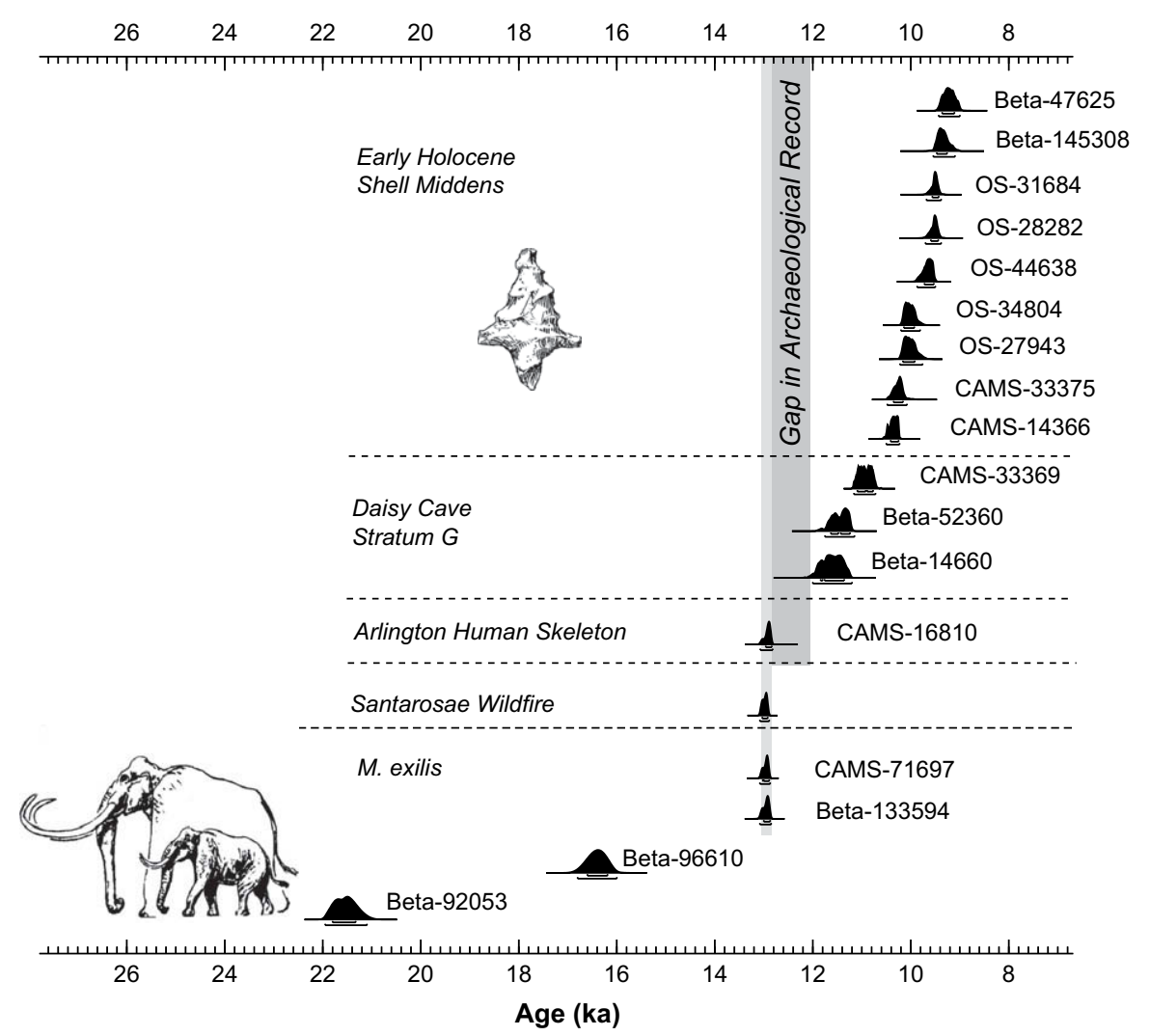

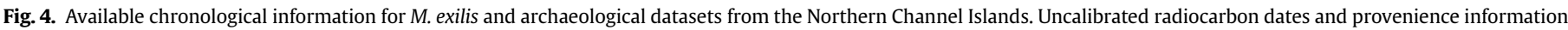

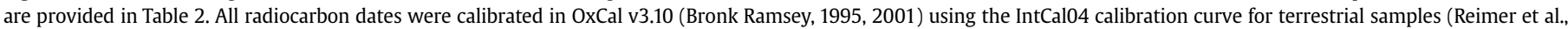

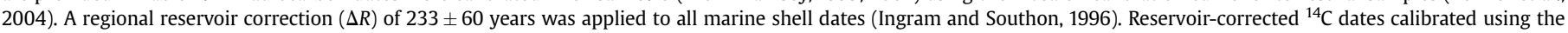

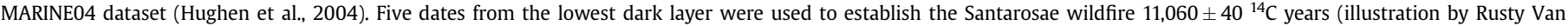
Rossman).

Santarosae, was favored by natural selection due to isolation, apparent lack of predators, lower carrying capacity and reduced food supply (Agenbroad, 2002a) and appears to have been the dominant species by the end of the Pleistocene.

Hundreds of $M$. exilis bones have been collected and curated during the last century, and at least 140 new fossil localities were identified on Santa Cruz, San Miguel, and Santa Rosa during a recent comprehensive study (Agenbroad, 2002b). The majority of these bones were found out of primary context and within alluvial deposits. Radiocarbon dates on associated charcoal range to the limits of the ${ }^{14} \mathrm{C}$ dating technique at $\sim 47 \mathrm{ka}$. One nearly complete $M$. exilis skeleton found on the north coast of Santa Rosa was directly dated to $\sim 16.3-13.9$ ka (Agenbroad, 1998). Finally, a thoracic vertebra (M. exilis) from the northwest coast of Santa Rosa Island was directly dated with modern techniques $11,030 \pm 50$ ${ }^{14} \mathrm{C}$ (CAMS-71697, XAD-purified collagen; Fig. 4, Table 2). The vertebra was found in the upper marine terrace and is associated with a charcoal date of $11,010 \pm 70{ }^{14} \mathrm{C}$ (Beta-133594). Therefore, a calibrated age of $13-12.9 \mathrm{ka}$ is presently considered to be a terminal age for $M$. exilis on the island (Agenbroad et al., 2005) - the onset of the YD.

\section{Wildfire and abrupt ecosystem disruption}

Sedimentary records from the Northern Channel Islands and SBB (ODP Site 893) indicate intense regional wildfires and abrupt ecosystem disruption at the Ållerød-YD transition ( 13-12.9 ka). This time interval coincides with a last possible occurrence of $M$. exilis and marks the beginning of an apparent 600-800-year gap in the archaeological record, both of which may be indications of ecosystem disruption on Santarosae. Evidence for periodic fires during the LGM is evident in sedimentary records from San Miguel Island (Johnson, 1972, 1977) and charcoal records from Soledad Pond and Abalone Rocks Marsh, both on Santa Rosa Island, indicate that small scale grass/brush fires were part of island ecology throughout the Holocene with increasing intensity in the Late Holocene and Historic Periods (Anderson, 2002). Here we present evidence for intense biomass burning of conifers and subsequent mass wasting of the landscape at 13-12.9 ka in Arlington Canyon (Santa Rosa Island, AC-003). This expands and complements preliminary evidence for $\sim 13 \mathrm{ka}$ wildfires discovered on San Miguel Island, the next island west of Santa Rosa (Firestone et al., 2007). Evidence for these wildfires is from the well-dated paleontological sediments at Daisy Cave (Stratum I, CA-SMI-261), which underlie the archaeological deposits that began accumulating at $\sim 12.2 \mathrm{ka}$ (Erlandson et al., 1996). Pinter and Anderson (2006) also have proposed Santarosae Island-wide "mega-fires" and landscape transformation at $\sim 13 \mathrm{ka}$.

The AC-003 section (UTM: 10S 0762524/3764532, Fig. 1) is located $\sim 1.35 \mathrm{~km}$ from the modern coastline and $1.2 \mathrm{~km}$ upstream from the Clovis-age Arlington locality. Arlington Canyon cuts through a series of uplifted Quaternary terraces that dominate the landscape north of the Santa Rosa Island fault and are well known for containing M. exilis remains (Orr, 1968; Agenbroad, 2002b). Holocene alluvial and colluvial deposits are exposed throughout Arlington Canyon, but AC-003 was selected because preliminary work by G. James West indicated that the basal deposits in the exposed sequence dated to the Ållerød-YD transition and appeared similar in character to the dark sedimentary layers described by Haynes (2008) across much of North America (Johnson et al., 2007). 


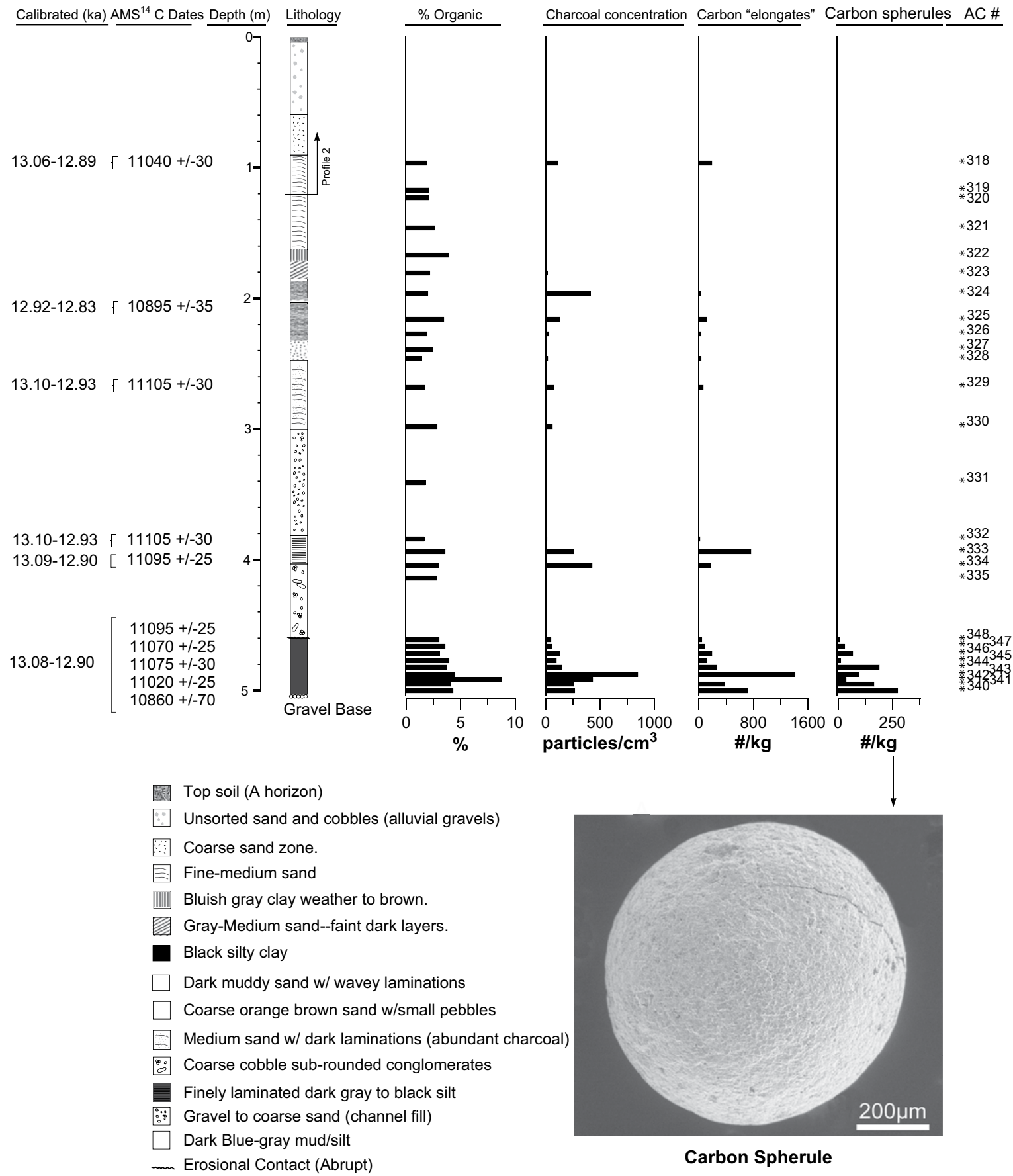

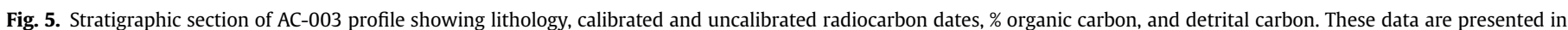

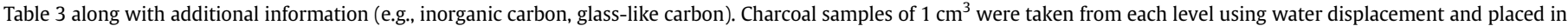

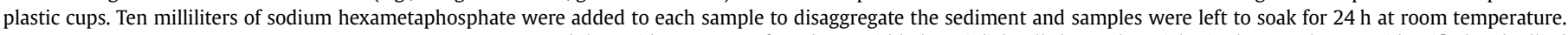

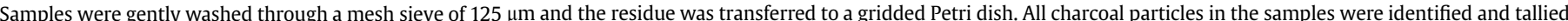

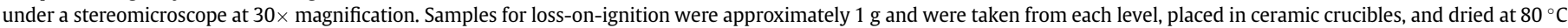

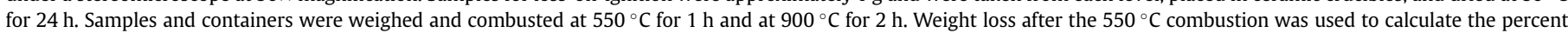

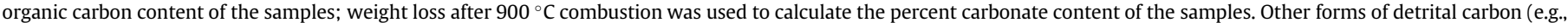

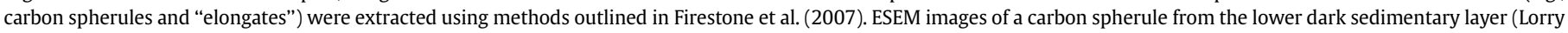
I. Lokey Nanoscience Laboratories, University of Oregon).

The section is exposed on the western side of the canyon at the base of a steep incline extending down from the Quaternary terrace above.

Fig. 5 shows the lithostratigraphy of the AC-003 section in addition to chronological information, \% organic and inorganic carbon, charcoal concentration, and detrital carbon morphological data (also see Table 3). The basal deposits of this section were exposed in 2001, but largely covered with modern alluvium in 2007, when we exposed and sampled the profile. The exposed $5 \mathrm{~m}$ thick sequence rests upon a basal gravel that is at modern stream level and is largely covered with alluvial sands and gravels. A distinctive organic carbon rich, dark blue-gray silty mud $(44 \mathrm{~cm}$ thick) directly overlays the basal gravel. The gleyed silty mud is capped with a coarse cobble channel lag deposit ( $\sim 60 \mathrm{~cm}$ thick) 
Table 3

Organic, inorganic, and other detrital carbon from AC-003.

\begin{tabular}{|c|c|c|c|c|c|c|c|}
\hline \multirow[t]{2}{*}{ Sample \# } & \multirow[t]{2}{*}{$\mathrm{cmbs}$} & \multirow[t]{2}{*}{$\%$ Organic } & \multirow[t]{2}{*}{ Charcoal \#/cm ${ }^{3}$} & \multirow[t]{2}{*}{ Herbaceous (\%) } & \multicolumn{3}{|l|}{ Detrital carbon } \\
\hline & & & & & Spherules (\#/kg) & Elongate $(\# / \mathrm{kg})$ & Glass-like ( $\mathrm{g} / \mathrm{kg}$ ) \\
\hline AC318 & $95-99^{a}$ & 1.870 & 115 & 7.83 & 0 & 192 & 0.000 \\
\hline АC 319 & $115-120^{a}$ & 2.080 & 2 & 0.00 & 0 & 0 & 0.000 \\
\hline AC 320 & $122-125$ & 2.044 & 0 & 0.00 & 0 & 0 & 0.000 \\
\hline AC321 & $145-148$ & 2.601 & 0 & 0.00 & 0 & 0 & 0.000 \\
\hline AC322 & $166-169$ & 3.870 & 0 & 0.00 & 0 & 0 & 0.000 \\
\hline AC323 & $179-183$ & 2.175 & 18 & 0.00 & 0 & 0 & 0.000 \\
\hline AC324 & $195-198$ & 1.991 & 413 & 8.72 & 0 & 23 & 0.001 \\
\hline AC325 & $215-217$ & 3.459 & 131 & 0.00 & 0 & 112 & 0.001 \\
\hline AC326 & $226-229$ & 1.920 & 31 & 0.00 & 0 & 30 & 0.001 \\
\hline AC327 & $238-241$ & 2.437 & 2 & 0.00 & 0 & 0 & 0.000 \\
\hline AC 328 & $245-248$ & 1.416 & 22 & 0.00 & 0 & 31 & 0.001 \\
\hline АC 329 & $267-270$ & 1.688 & 76 & 1.32 & 0 & 66 & 0.000 \\
\hline AC330 & $297-300$ & 2.838 & 65 & 0.00 & 0 & 0 & 0.001 \\
\hline AC331 & $340-343$ & 1.769 & 5 & 0.00 & 0 & 0 & 0.000 \\
\hline AC332 & $383-386$ & 1.648 & 13 & 0.00 & 0 & 18 & 0.000 \\
\hline AC333 & $392-396$ & 3.583 & 261 & 0.00 & 0 & 767 & 0.001 \\
\hline AC334 & $403-406$ & 2.959 & 430 & 0.23 & 0 & 173 & 0.001 \\
\hline AC335 & $413-416$ & 2.785 & 0 & 0.00 & 0 & 0 & 0.000 \\
\hline AC 348 & $459-464$ & 3.025 & 51 & 0.00 & 8 & 42 & 0.001 \\
\hline АС 347 & $464-469$ & 3.577 & 58 & 0.00 & 31 & 81 & 0.001 \\
\hline АC 346 & $469-475$ & 3.075 & 132 & 0.00 & 68 & 193 & 0.001 \\
\hline AC345 & $475-480$ & 3.929 & 102 & 0.00 & 13 & 113 & 0.001 \\
\hline AC 344 & $480-485$ & 3.720 & 148 & 0.00 & 190 & 264 & 0.001 \\
\hline AC 343 & $485-491$ & 4.472 & 849 & 0.24 & 85 & 1412 & 0.001 \\
\hline АС 342 & $491-493$ & 8.719 & 435 & 6.90 & 38 & 0 & 0.000 \\
\hline AC341 & $493-498$ & 4.069 & 258 & 1.55 & 166 & 373 & 0.001 \\
\hline AC 340 & $498-503$ & 4.310 & 268 & 0.37 & 274 & 714 & 0.001 \\
\hline
\end{tabular}

a profile 2.

and a second dark layer $(20 \mathrm{~cm}$ thick) consisting of finely laminated dark gray to black sandy silt. The upper dark layer is also organic carbon rich and contains charcoal and charred tree branches up to $5 \mathrm{~cm}$ in diameter. Intense wildfire evidence is also indicated by the presence of carbon spherules $(400-1500 \mu \mathrm{m})$ in the lowest dark layer (see Fig. 5). These spherules occur widely in the YDB layer in North America and have also been found in surficial sediments associated with intense coniferous forest crown fires (Firestone et al., 2007). Elongated carbon forms found in a number of levels in the sequence have similar surface features to the carbon spherules. Both carbon forms have (1) the appearance of melted and charred organic matter, (2) a moderately glossy shell unlike that of charcoal, and (3) interior vesicles that are typically a few micrometers in diameter. However, there are at least three important differences between the two carbon types. Carbon elongates are not spherical, but are approximately 2-3 times longer than they are wide, they have a much coarser spongy interior cellular structure, and they are found throughout the sequence whereas carbon spherules occur only in the lowest black layer. The remainder of the sequence consists of alluvial sands and gravels and includes additional charcoal-rich layers. Charcoal layers in the upper section are thinner and dispersed and do not form a distinctive black layer as with the lowest deposits.

AMS ${ }^{14} \mathrm{C}$ dates for the lower black organic carbon-rich layers suggest that they accumulated rapidly at $\sim 13.0-12.9$ ka (Table 4 ). Five of the AMS ${ }^{14} \mathrm{C}$ dates for the lower black layer are slightly older,

Table 4

Radiocarbon dates from the AC-003 stratigraphic section.

\begin{tabular}{|c|c|c|c|c|c|c|}
\hline Lab \# & Depth $(\mathrm{cm})$ & Lithological unit $^{\mathrm{a}}$ & Material dated & ${ }^{14} \mathrm{C}$ & $\pm \leftarrow$ & Cal. ${ }^{\mathrm{C}}$ age (BP) \\
\hline UCIAMS-47235 & $95-99$ & Unsorted sand and cobbles (alluvial gravels) & Charcoal & 11,040 & 30 & $13,060-12,890$ \\
\hline UCIAMS-47236 & $179-183$ & Gray-medium sand-faint dark layers & Charcoal & 12,095 & 40 & $14,060-13,820^{\mathrm{e}}$ \\
\hline UCIAMS-47237 & $215-217$ & Black silty clay & Charcoal & 10,895 & 35 & $12,915-12,830$ \\
\hline UCIAMS-47238 & $267-270$ & Gray sand w/laminations (abundant charcoal) & Charcoal & 11,105 & 30 & $13,100-12,930$ \\
\hline UCIAMS-47239 & $392-396$ & Finely laminated dark gray to black silt & Charcoal & 11,105 & 30 & $13,100-12,930$ \\
\hline UCIAMS-42816 & $403-406$ & Finely laminated dark gray to black silt & Wood $^{\mathrm{b}}$ & 11,095 & 25 & $13,090-12,930$ \\
\hline UCIAMS-36308 & 464-469 & Blue-gray mud/silt & Wood & 11,095 & 25 & $13,090-12,930$ \\
\hline UCIAMS-36307 & $469-475$ & Blue-gray mud/silt & Wood & 11,070 & 25 & $13,070-12,910$ \\
\hline UCIAMS-36306 & $485-491$ & Blue-gray mud/silt & Wood & 11,375 & 25 & $13,310-13,180^{f}$ \\
\hline UCIAMS-36959 & $480-485$ & Blue-gray mud/silt & Charcoal & 11,075 & 30 & $13,080-12,910$ \\
\hline UCIAMS-36960 & $480-485$ & Blue-gray mud/silt & Glassy carbon & 11,185 & 30 & $13,190-12,980^{f}$ \\
\hline UCIAMS-36961 & $480-485$ & Blue-gray mud/silt & Carbon sphere & 11,440 & 90 & $13,470-13,120^{\mathrm{f}}$ \\
\hline UCIAMS-36962 & $480-485$ & Blue-gray mud/silt & Carbon Brecchia "elongate" & 11,110 & 35 & $13,110-12,930^{f}$ \\
\hline Beta-161032 & $480-485$ & Blue-gray mud/silt & Wood (yellow pine-Diploxylon) ${ }^{\mathrm{d}}$ & 10,860 & 70 & $12,940-12,780$ \\
\hline UCIAMS-36305 & $493-498$ & Blue-gray mud/silt & Wood & 11,235 & 25 & $13,220-13,080^{f}$ \\
\hline UCIAMS-36304 & $498-503$ & Blue-gray mud/silt & Wood & 11,020 & 25 & $13,040-12,880$ \\
\hline
\end{tabular}

\footnotetext{
a See Fig. 4 for stratigraphic position.

b Large log in stratum (outer portion sampled).

c 2 sigma, IntCal04.

d Original sample collected by G. James West.

e Rejected-out of stratigraphic sequence.

f Not included in average age of lowest stratigraphic unit due to "old wood" effect.
} 
Table 5

Raw, percent and pollen concentration values for AC-003 sediments.

\begin{tabular}{|c|c|c|c|c|c|c|c|c|c|c|c|c|c|c|}
\hline Depth (cmbs) \% & 245 & $\%$ & 394 & $\%$ & 401 & $\%$ & 445.5 & $\%$ & 447.5 & $\%$ & 458 & $\%$ & 460 & $\%$ \\
\hline Pinus & 11 & 15 & 43 & 37 & 98 & 38 & 65 & 41 & 37 & 29 & 62 & 38 & 49 & 26 \\
\hline $\mathrm{TCT}^{\mathrm{a}}$ & 38 & 51 & 45 & 39 & 130 & 50 & 53 & 33 & 73 & 57 & 80 & 49 & 120 & 64 \\
\hline Quercus & 13 & 17 & 12 & 10 & 12 & 5 & 6 & 4 & 4 & 3 & 2 & 1 & 0 & 0 \\
\hline Juglans & 0 & 0 & 0 & 0 & 0 & 0 & 0 & 0 & 1 & 1 & 0 & 0 & 0 & 0 \\
\hline Rhus & 1 & 1 & 2 & 2 & 0 & 0 & 2 & 1 & 0 & 0 & 2 & 1 & 1 & 1 \\
\hline Rhamnaceae & 1 & 1 & 3 & 3 & 0 & 0 & 5 & 3 & 2 & 2 & 3 & 2 & 0 & 0 \\
\hline Rosaceae & 4 & 5 & 0 & 0 & 2 & 1 & 10 & 6 & 3 & 2 & 1 & 1 & 2 & 1 \\
\hline Artemisia & 1 & 1 & 0 & 0 & 1 & c & 2 & 1 & 0 & 0 & 0 & 0 & 1 & 1 \\
\hline Aster Hi & 0 & 0 & 0 & 0 & 2 & 1 & 13 & 8 & 0 & 0 & 2 & 1 & 0 & 0 \\
\hline Aster Low & 1 & 1 & 4 & 3 & 4 & 2 & 0 & 0 & 1 & 1 & 5 & 3 & 5 & 3 \\
\hline Liguliflorae & 0 & 0 & 1 & 1 & 0 & 0 & 1 & 1 & 0 & 0 & 1 & 1 & 0 & 0 \\
\hline Poaceae & 5 & 7 & 3 & 3 & 5 & 2 & 0 & 0 & 1 & 1 & 2 & 1 & 5 & 3 \\
\hline Chenopodiaceae & 0 & 0 & 0 & 0 & 6 & 2 & 3 & 2 & 3 & 2 & 3 & 2 & 1 & 1 \\
\hline Polygonaceae & 0 & 0 & 1 & 1 & 0 & 0 & 0 & 0 & 2 & 2 & 0 & 0 & 2 & 1 \\
\hline Eriogonium & 0 & 0 & 1 & 1 & 1 & c & 0 & 0 & 0 & 0 & 0 & 0 & 1 & 1 \\
\hline Apiaceae & 0 & 0 & 0 & 0 & 0 & 0 & 0 & 0 & 0 & 0 & 0 & 0 & 1 & 1 \\
\hline Salix & 0 & 0 & 2 & 2 & 2 & 2 & 0 & 0 & 0 & 0 & 1 & 1 & 1 & 1 \\
\hline Cyperaceae $^{\mathrm{b}}$ & 7 & 6 & 0 & 0 & 2 & 1 & 0 & 0 & 0 & 0 & 0 & 0 & 1 & 1 \\
\hline Juncus ${ }^{\mathrm{b}}$ & 28 & 25 & 0 & 0 & 6 & 0 & 3 & 2 & 4 & 3 & 0 & 0 & 0 & 0 \\
\hline Isoetes & 0 & 0 & 0 & 0 & 0 & 0 & 0 & 0 & 0 & 0 & 1 & 1 & 2 & 1 \\
\hline Unkn/undiff & 119 & 52 & 105 & 47 & 131 & 33 & 74 & 31 & 73 & 36 & 63 & 28 & 129 & 40 \\
\hline Grains/cc & 5155 & & 26,530 & & 29,480 & & 26,676 & & 10,393 & & 172,626 & & 86,313 & \\
\hline
\end{tabular}

a Juniperus-Cupressus.

b Outside pollen sum.

c Present $<1 \%$

but there is no stratigraphic correlation and they all fall within the expected range if the pith wood of old trees burned in a wildfire. Conifer forest (Pinus and Juniperus-Cupressus) partly covered the landscape in the latest Ållerød (13-12.9 ka) according to the pollen evidence (Table 5), an observation consistent with pollen and macrobotanical evidence from Santa Cruz and San Miguel Islands (Chaney and Mason, 1930; Fergusson and Libby, 1964; Johnson, 1977; West, 1994; Anderson, 2002). Biomass burning at 13-12.9 ka was followed by erosion with sediments containing charcoal, wood, and detrital carbon filling the channel. This organic carbon-rich dark layer was then rapidly buried and preserved by a series of mass sediment wasting events of a denuded early YD landscape. Pollen grains are poorly preserved, highly eroded and corroded, and have been reworked in the upper deposits in this section. The upper $4 \mathrm{~m}$ of the deposit also date to between 13 and $12.9 \mathrm{ka}$ indicating periodic fires and mass sediment wasting of the landscape in close succession in the early YD or rapid redeposition of material from the lowest burn layer in subsequent mass wasting events. If the latter, then the upper diffuse charcoal layers are not a proxy for fire activity, but a marker of sediment input from parts of the watershed burned at the YDB and deposited soon after this event during wet conditions promoting erosion. If the former, then the fires were clearly less intense and derived from already dead materials on the landscape. Regardless, it is clear that sediments accumulated rapidly during the early YD at this location after $12.9 \mathrm{ka}$ and then stopped. This indicates that the channel incised soon after this catastrophic event, trapping the stream in the canyon for much of the YD and Holocene. The stratigraphic and chronological evidence from AC-003 clearly suggest mass sediment sediment wasting of the landscape in the wake of intense biomass burning. Only modest evidence for fire during the YD is evident in the nearby Soledad Pond sequence, a record that begins at $\sim 12.5 \mathrm{ka}$ and is notable for the virtual absence of conifer pollen and the dominance of non-arboreal plant taxa (e.g., sunflower [Asteraceae], coyote brush [Baccharis]), suggesting that the transition to non-arboreal vegetation on Santarosae was rapid (Anderson, 2002, p. 10)

Evidence for intense wildfire and abrupt ecological disruption on the Northern Channel Islands is consistent with the vegetation and charcoal records from SBB ODP Site 893 (Heusser, 1995, 1998; Heusser and Sirocko, 1997), the longest and most continuous available for the Santa Barbara Channel region (Fig. 6). Pollen assemblages reflect vegetation changes on the adjacent coasts. These pollen records accumulated in Santa Barbara Basin sediments via eolian and water transport. This pollen spectrum is dominated by pine (Pinus) and juniper-cypress (JuniperusCupressus) during the LGM, and these conifers persisted in the region throughout the Bølling-Ållerød. Oak [Quercus] woodlands gradually expanded in the region after 16 ka suggesting increasingly warm, seasonally dry conditions during the Ållerød. The onset of the YD closely correlates with a major abrupt decline in the abundance of Juniperus-Cupressus pollen suggesting that these trees were abundant regionally before, but not after, $\sim 13-12.9 \mathrm{ka}$. Spikes in Pinus pollen during the early YD, after major reductions in Juniperus-Cupressus, suggest that it played a successional role in southern California coniferous forests (Heusser and Sirocko, 1997, pp. 243) and soon also diminished. This major reduction in the montane forest vegetation corresponded with a distinct increase in grass and herbs (mainly from the Asteraceae family), suggesting a regional shift to more open habitats dominated by grasslands, coastal sage, and chaparral communities with dispersed stands of oak; vegetation that dominates in the region throughout the YD and Holocene (Heusser, 1998). Range restrictions in JuniperusCupressus are unlikely a product of YD cooling given the abundance and extent of these taxa during the LGM. The YD is generally considered to be a dry interval in western North America relative to the Ållerød wet period (Allen and Anderson, 1993; Broecker, 1994; Benson et al., 1996). Gradual increases in oak pollen starting at 16 ka suggest that seasonally dry conditions were developing and were in place by the YD. Pinus events evident in the early YD indicate strong winter monsoon rains and dry, hot summers (Heusser and Sirocko, 1997, pp. 244). This is consistent with other western North American evidence that conditions at the ÅllerødYD boundary were seasonally wet (Haynes, 2008), at least during the early YD.

The abrupt reduction in conifers and the shift to more open habitats regionally correlates with the most extreme pollen minima and charcoal maxima of the last 25,000 years in ODP Site 


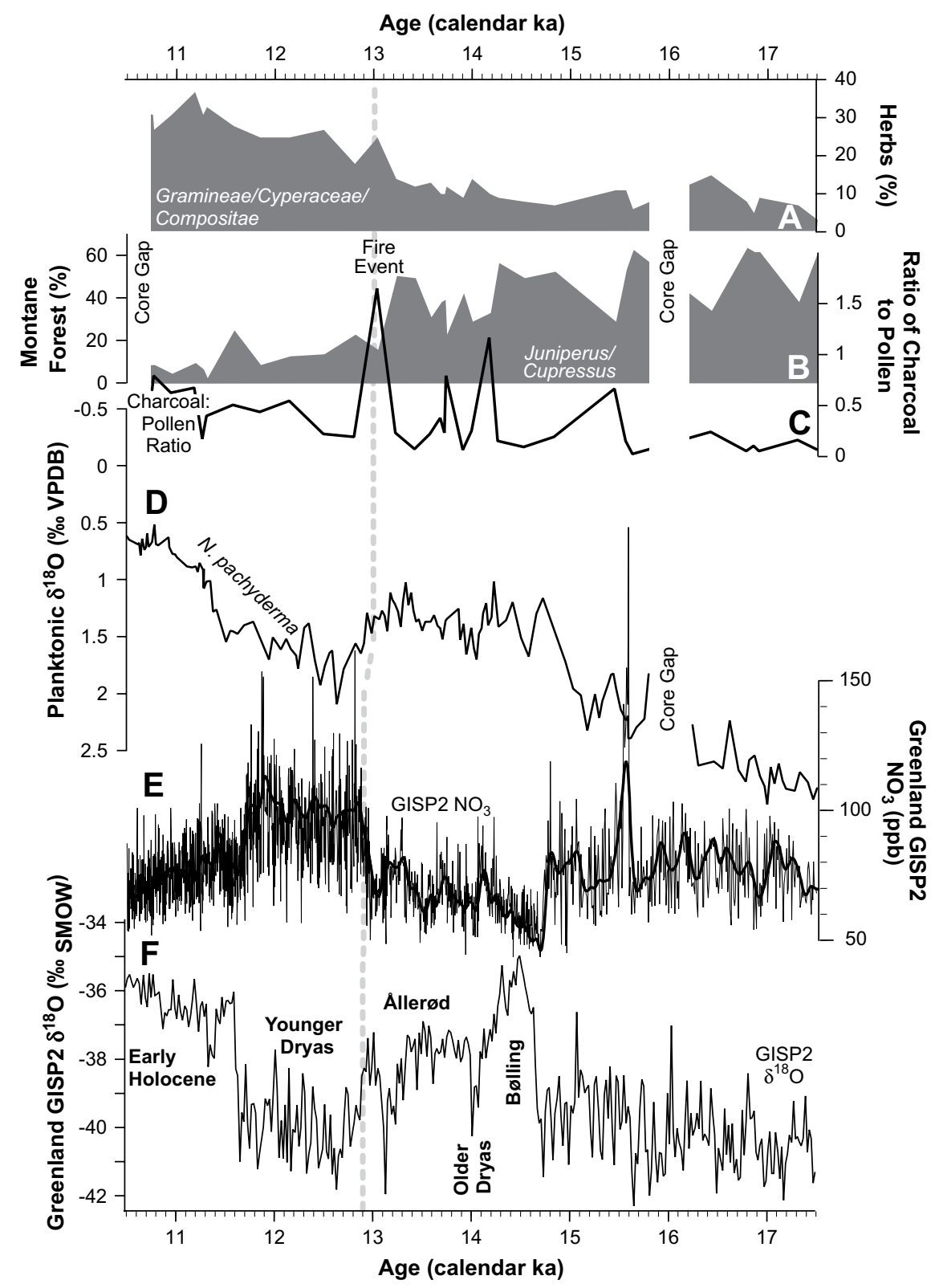

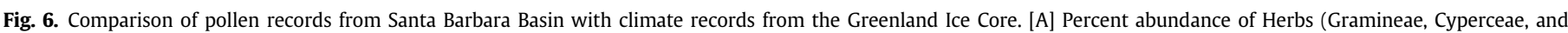

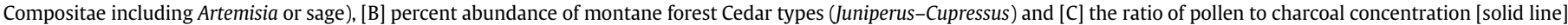

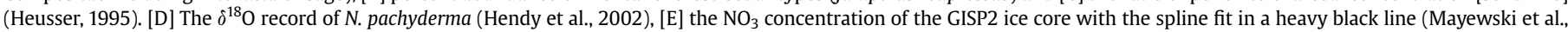
1993) and [F] the GISP2 $\delta^{18} \mathrm{O}$ record (Stuiver and Grootes, 2000). Gray dashed line marks the initiation of the Younger Dryas cooling event.

893, interpreted as a wildfire indicator (Heusser and Sirocko, 1997). This suggests rapid ecosystemic change in the wake of major regional wildfires and associated landscape disturbance. These changes are consistent with the record of wildfire from the upper Arlington Canyon section and evidence for abrupt change in island vegetation during the YD. Fuel build-up from Late Pleistocene conifer forests and gradual drying through the Bølling/ Ållerød are indicated by the expansion of oak starting at $16 \mathrm{ka}$ (Heusser and Sirocko, 1997) and would have contributed to the intense nature of this conflagration. The deeply buried dark layer (a sapropel) evident in the AC-003 section accumulated under wet conditions that contributed to the anoxia necessary to preserve the organic matter. Rapid deposition of sediments in the early YD is also consistent with increased precipitation transferring sediment from the surrounding denuded landscape. When the AC-003 sequence is considered within the context of existing Late
Quaternary vegetation and fire records for the islands (Anderson, 2002; Pinter and Anderson, 2006; Firestone et al., 2007), it appears that biomass burning at 13-12.9 ka was island-wide and marks a major shift in vegetation and fire regime. The SBB record extends the distribution of the biomass burning and associated shift in vegetation regionally. Organic carbon burial rates in Santa Barbara Basin increase at the beginning of the YD, a process linked to increase in ballast minerals and higher sedimentation rates (Nederbragt et al., 2008). Gradual increase in organic carbon deposition may be related to sea-level rise as the margins of SBB have been implicated as temporary storage areas $(+200$ years $)$ for sediments without significant ballast. However, the large increase in organic carbon burial rates at the onset of the YD is also consistent with mass sediment wasting of the landscape in the wake of extensive biomass burning on the adjacent islands and mainland. 


\section{Discussion}

Biological communities on islands are inherently fragile and animal populations are vulnerable to extinction. This is because breeding populations are small and isolated from mainland populations. Ecological perturbations, whether through natural environmental change, human-induced environmental catastrophes, or direct hunting, will have far greater effects on island ecosystems than on nearby, contemporaneous mainland faunas. Late Pleistocene biological communities on Santarosae were no exception. M. columbi was the only member of the mainland's diverse Rancholabrean fauna to colonize these offshore islands, probably significantly before $47 \mathrm{ka}$ (Agenbroad, 1998). M. exilis resulted from evolution by natural selection in this insular environment and in the absence of predators (Agenbroad, 2002b). This species was highly adapted to this depauperate terrestrial environment as evidenced by its survival and persistence during the multiple abrupt warming and cooling episodes that marked the Late Quaternary (Hendy and Kennett, 1999).

The available data are support for a $M$. exilis extinction at 13-12.9 ka (Agenbroad et al., 2005). Gradual changes in sea-level between 17.5 and $13 \mathrm{ka}$ reduced island area by $\sim 32 \%$. The most rapid landmass decrease is evident during the Bølling/Ållerød, between 14.5 and $13.4 \mathrm{ka}$. If $M$. exilis populations were adapted to the coastal lowlands of Santarosae then this would have had a significant impact on the population (Agenbroad, 1998, 2002a). However, only modest sea-level rise occurred across the ÅllerødYD boundary and fragmentation of island habitats through formation of the four separate islands commenced later after $10.8 \mathrm{ka}$. Reductions in foraging range associated with sea-level rise between 17.5 and $13 \mathrm{ka}$ certainly would have reduced $M$. exilis populations and increased their vulnerability to extinction. However, the modest habitat loss across the Ållerød-YD boundary cannot explain the seemingly abrupt extinction at 13-12.9 ka. Abrupt cooling evident in SBB ODP Site 893 is also an unlikely explanation for $M$. exilis extinction at 13-12.9 ka because previous cooling and warming episodes during the Late Quaternary were equally abrupt.

The earliest evidence presently known for a human occupation of Santarosae (at Arlington Springs) closely coincides with the last evidence for $M$. exilis. This coincidence forms the basis for the hypothesis that the extirpation of $M$. exilis was human induced (Agenbroad et al., 2005). Human-induced extinction of the largest, ecologically vulnerable, prey is well documented in similar island settings and occurs with clear evidence for human colonization, population increases, and dietary expansion (Anderson, 1989; Steadman, 1995; Patton, 1996). In these cases the bones of target species (e.g., Moa in New Zealand, Anderson, 1989) are found in early colonization sites and several hundred years pass before these animals were completely extirpated. This often occurs with clear evidence for expanding agricultural populations.

The skill and technology needed to hunt large animals was clearly present on the adjacent mainland between $\sim 13.3$ and 12.9 ka (Erlandson et al., 2007; Rondeau et al., 2007). Behavioral ecological theory predicts that these large animals would have been targeted when humans colonized these islands (Kennett, 2005, p. 220), but there is yet no direct evidence that these animals were hunted. Orr (1968) argued for the coeval existence of $M$. exilis and humans on Santarosae as early as 40,000 years ago. In a series of controversial articles, Orr and Berger argued that the close physical association of mammoth bones, crude stone tools and "hearths" indicated a clear Pleistocene occupation of the island by humans (Orr and Berger, 1966; Berger and Orr, 1966; Berger, 1980, 1982). Subsequent work suggested that the associations of flaked tools and bones could have easily resulted from natural processes, and some of the fire areas (hearths) may have been a product of chemical weathering (Johnson, 1972). In fact, close to a century of paleontological and archaeological work has failed to locate a single M. exilis kill locality. Of the 140 Mammuthus localities identified in a recent comprehensive survey of these islands (Agenbroad, $2002 \mathrm{~b}$ ), there are no reported bones with cut marks or human artifacts associated with them. No early colonization sites containing the bones of these animals have been identified. However, because none of these localities has direct ${ }^{14} \mathrm{C}$ dates the 140 mammoth localities recorded theoretically span a long period of time (13 ka to $>50 \mathrm{ka}$ ). If humans were recent occupants of the Santarosae (13.1 ka), only a small number of Mammuthus specimens would overlap with human presence. The taphonomy of deposition is also against discovering kill sites. Bones in upland kill sites would disintegrate rapidly unless they were rapidly redeposited, and if so, this would scatter artifact evidence widely. However, the Clovis-like spear point technology present on the California mainland has not been found on these islands. Even with the problems associated with site burial or loss related to sea-level rise (Kennett, 2005), the complete absence of evidence that these animals were hunted is puzzling and currently inconsistent with the human overkill hypothesis.

At present, the Arlington human skeletal material provides the only direct evidence for human presence on Santarosae at $~ 13.1-$ $12.9 \mathrm{ka}$. The partial remains of this individual occur in a small arroyo that filled with sediment during the YD then was later exposed near the mouth of the modern Arlington drainage. Although it is possible that Santarosae was permanently occupied by this time there is currently no evidence for other archaeological sites that would suggest a large population. The presence of humans on this offshore island is unequivocal evidence that peoples living along the mainland coast of western North America possessed boats and advanced maritime technologies. If primary settlements were located along the coast of Santarosae and were submerged or destroyed during sea-level rise, this would suggest a maritime adaptation rather than one focused on the hunting of large game animals. The current absence of interior kill sites seems consistent with this interpretation.

A possible gap in the record during much of the YD ends at $\sim 12.2$ ka with evidence for Paleoindian occupations of Cardwell Bluffs and Daisy Cave on western Santarosae (San Miguel Island; see Erlandson, 2007; Erlandson et al., in press). This time gap is partly explained by fluctuations in the radiocarbon calibration curve in the early YD, including a plateau of $\sim 200$ years (Muscheler et al., 2008). These fluctuations can make events and gaps in the record look more or less abrupt and calibrating radiocarbon dates is essential (Bartlein et al., 1995). Regardless, more extensive evidence for human occupation of Santarosae is only seen in the proliferation of terminal Pleistocene and Early Holocene shell middens between 10.2 and 9 ka-sites associated with evidence for a maritime adaptation (Rick et al., 2005; Erlandson et al., 2007). Solid evidence for human occupation of the islands preceded the stabilization of sea-level and loss of coastal habitat by $\sim 4000$ years, with numerous early sites found in caves, near fresh water springs, and around toolstone sources that drew maritime peoples away from now submerged shorelines. This suggests that the evidence for earlier human occupation is not entirely lost to Late Quaternary sea-level rise and coastal erosion. Data from ODP Site 893 indicate that marine productivity remained at least seasonally high along the California margin during the YD and terrestrial climate records from North America suggest that the early part of this interval was likewise seasonally moist. The absence of evidence for a human presence on Santarosae is therefore unlikely to be a product of climate-driven decreases in marine or terrestrial productivity.

Beyond Santarosae there is currently little evidence for a substantial population in California during the YD (Jones et al., 
2002; Erlandson et al., 2007). Clovis-like fluted points have been identified at 51 locations (see Fig. 1a), representing nearly every type of environmental setting-except the Channel Islands (Dillon, 2002; Rondeau et al., 2007). There remains some uncertainty about the chronology of Clovis-like points in California. Only two sites, Borax Lake (LAK-36; Meighan and Haynes, 1970) and Skyrocket (CAL-629/630; Bieling et al., 1996) have produced Clovis-like points stratigraphically below Early Holocene occupation levels. In both cases, radiometric dating of these deposits is uncertain, but they clearly pre-date Early Holocene materials based on superposition (Skyrocket) and obsidian hydration measurements (Borax Lake). No archaeological sites in mainland California have been convincingly radiocarbon-dated between 12.9 and $12 \mathrm{ka}$ and only a few date between 12 and $11 \mathrm{ka}$. In contrast, more than 38 sites have produced radiocarbon evidence for occupation between 10.5 and $9 \mathrm{ka}$ (see Erlandson et al., 2007). The vast majority of these sites provide no evidence for earlier Pleistocene occupation. The earliest archaeological record from California is therefore marked by a possible gap between the Late Pleistocene and the Early Holocene. If the age of fluted projectile points in California equates with the recently revised age for Clovis over North America (Waters and Stafford, 2007, p. 1123) of 13.3-12.9 ka, then this could represent a depression in mainland human occupation that extends between $\sim 12.9$ and $10.5 \mathrm{ka}$. While the chronology of this hiatus remains poorly defined, the time gap between the Clovis-like fluted point tradition and Early Holocene records is widespread and remarkable (Jones, 2007). Much more work is needed in California. We simply point out that there is currently an absence of archaeological sites dating to much of the YD and the millennium following it, which is potentially consistent with broader-scale ecosystem disruption at 13-12.9 ka.

Wildfire, mass wasting, and reduction in forage at 13-12.9 ka are possible mechanisms for abrupt $M$. exilis extinction on Santarosae, a scenario in which human hunters could still have played some 'coup de grace' role. These intense wildfires occurred after a substantial build-up of fuel from Late Pleistocene conifer forests and in the context of regional drying that started $\sim 16 \mathrm{ka}$. Humaninduced fires and associated habitat loss are among several interlinked mechanisms proposed for large herbivore extinction in Madagascar (Burney, 1993; Burney et al., 2003). These extinctions occurred in the Late Holocene (after $1.7 \mathrm{ka}$ ) in association with expanding agricultural populations and clear human transformation of the landscape. The purposeful use of fire for land clearing is well known in agricultural societies (Posey, 1985; Piperno et al., 1991; Smith, 2001; Kennett et al., 2006a,b). Huntergatherers are known to use fire to alter landscapes for economic purposes (Yen, 1989) and this was well documented historically in California (Anderson, 2005). However, the apparent low human population levels on Santarosae at $\sim 13.1-12.9$ ka and major conflagrations are generally inconsistent with resource management and the hypothesis that these fires were of anthropogenic origin (contra Pinter and Anderson, 2006).

The organic carbon-rich sediments at the base of the AC-003 sequence containing wildfire proxies co-occur with regional evidence for wildfire and ecosystem disruption in the form of major vegetation shifts and animal extinction on the islands and possibly more broadly in southern California (Marcus and Berger, 1984). The age of this deposit is equivalent $(\sim 13.0-12.9 \mathrm{ka})$ to the base of a distinctive black layer (YDB) found broadly across North America at 70 localities (Haynes, 2005, 2008). Dark sedimentary layers can develop locally for a variety of natural and anthropogenic reasons (see Quade et al., 1998), but this dark, geographically extensive layer occurs directly above extinct Pleistocene animal remains (Haynes, 2005, 2008). Clovis artifacts associated with the remains of select fauna occur in terminal Pleistocene alluvial or spring deposits and are also capped by this distinctive black sedimentary layer at Blackwater Draw, NM, Murray Springs, AZ, Lehner, AZ, UP Mammoth, Colby, and Domebo (Holiday, 1985; Taylor et al., 1996; Haynes, 2005, 2007, 2008) and other Clovis-age sites (Lubbock Lake, TX; Holiday, 1985). The base of this dark stratum at Murray Springs (AZ, Clanton Ranch member-Stratum F1): is well dated to between 13 and $12.9 \mathrm{ka}$; it marks a major and continent-wide biostratigraphic change; and it serves as a major boundary with Pleistocene fauna occurring directly below and never above this easily discernable bed (Haynes, 2005). This black stratum (termed the Black Mat) contains organic matter derived from oxidized plant material and algae suggesting a shallow pond or marshy environment (Haynes, 2007, p. 45). Petrographic work indicates the presence of charcoal, vitreous carbon, vitrinite, and spores. PyrolysisGC/MS analysis suggests that the organic matter was derived from aromatic biomolecules typical of mature coals or burned wood fragments (Haynes, 2007, p. 245, report by Stankiewicz and Tegelaar). These characteristics are consistent with intense wildfires indicated by the presence of soot in this same stratum (Firestone et al., 2007). Hemispheric biomass burning is also indicated at the onset of the YD by large increases in ammonium and nitrate values in the Greenland GISP2 ice core (Mayewski et al., 1993, 1997; see Fig. 6).

Two independent research groups have now identified peaks in metallic microspherules at the base of this distinctive black layer (YDB) at Murray Springs (Firestone et al., 2007; Haynes, 2008). Preliminary work indicates that the abundance of microspherules at Murray Springs and at many other localities in North America cooccur with other apparent cosmic impact markers (e.g., above background concentrations of iridium; Firestone et al., 2007). Elevated iridium levels correlate with extensive wildfire at the K/T boundary (Köeberl, 2007, p. 33; Wolbach et al., 1985). The recognition of mass extinction at the $\mathrm{K} / \mathrm{T}$ boundary attributed to a major extraterrestrial impact along with the presence of a significant number of the same cosmic impact markers identified in the YDB provide an empirical basis for hypothesizing that the massive North American animal extinctions may have resulted from the direct effects of a cosmic impact (shockwave, heat, flooding, and wildfires) and subsequent cascading ecological changes associated with rapid climate change. This viable and testable hypothesis seems consistent with the evidence for wildfire, ecosystem disruption, animal extinction, and human population reduction on the Channel Islands and possibly more broadly in California. It is hypothesized that wildfires were ignited broadly across the continent and resulted from multiple aerial impacts that produced a severe radiation flux represented by intense fireballs distributed widely (Firestone et al., 2007). The evidence for biomass burning at the YDB in the Santa Barbara channel region is consistent with the hypothesis of broad continental biomass burning at this time. Furthermore the evidence for such a conflagration on Santarosae Island, a relatively small and isolated landmass supports the possibility that such an airburst barrage included the southern California region.

\section{Conclusions}

A dark black, deeply buried organic carbon-rich layer in Arlington Canyon (AC-003), dating to the Ållerød-YD boundary (13-12.9 ka), has produced high concentrations of charcoal, "elongate" carbon particles, and carbon spherules indicative of intense biomass burning on Santarosae at this time. This was followed by landscape mass sediment wasting that continued into the early YD. Near consistency of radiocarbon ages throughout much of the $\sim 5 \mathrm{~m}$ sediment sequence indicates that these sediments accumulated rapidly during the early YD. Later fires during this interval are recorded by thin charcoal-rich layers also containing charcoal, glass-like carbon, and "elongate" carbon particles, although these materials could have been redeposited following 
the erosion of original YDB sediments located upslope or upstream. It seems unlikely that a very small population of hunter-gatherfisher peoples triggered these wildfires. The absence of a range of other archaeological site types contemporary with the Arlington human skeleton suggests this early human presence was small and is inconsistent with extensive use of fire to transform landscapes for subsistence purposes. The possible absence of humans on the islands for 600-800 years following these wildfires is also inconsistent with anthropogenic burning. Finally, although there were clearly episodic wildfires on the Northern Channel Islands throughout the LGM and the Holocene, the intensity of the conflagration at $12.9 \mathrm{ka}$ suggests that a fundamentally different process may have occurred at the YDB.

The last known occurrence of $M$. exilis on Santarosae is 13-12.9 ka (Agenbroad et al., 2005). M. exilis populations were small and almost certainly would have contracted with coastal plain habitat loss associated with sea-level rise between 19.5 and $13 \mathrm{ka}$ (Agenbroad, 2002b). However, the fragmentation of Santarosae into its four modern islands did not occur until after the YD ( $\sim 10.8-9 \mathrm{ka})$ and there were no abrupt losses of habitat at 13-12.9 ka to trigger final extinction. Abrupt cooling at the onset of the YD in the SBB ODP Site 893 record is similar in magnitude to earlier abrupt climatic episodes during the Late Quaternary and thus does not help explain final extinction. The co-occurrence of the first evidence for human exploration of Santarosae and/or the terminal age of $M$. exilis is tantalizing. Human predation pressure or anthropogenic ecosystem disruption is a plausible hypothesis in this insular environment (Agenbroad et al., 2005; Kennett, 2005; Pinter and Anderson, 2006). However, there currently is no evidence for significant human presence on the island before 13.1$12.9 \mathrm{ka}$. This near lack of evidence cannot simply be explained as resulting from sea-level inundation of coastal plains. Humans were clearly present on the Channel Islands and throughout California between 13.1 and $12.9 \mathrm{ka}$. There is negligible evidence for human populations on the islands or elsewhere in California during most of the YD. This provides an empirical foundation for hypothesizing that there were major reductions in human populations during the YD. This hiatus is not easily explained by abrupt cooling given that the average temperature drop was only a few degrees Celsius in coastal California and particularly because marine conditions remained relatively productive through this interval.

Wildfire and mass sediment wasting of the landscape in Arlington Canyon are synchronous with evidence for wildfires at Daisy Cave on San Miguel Island (Firestone et al., 2007) and "megafires" elsewhere on Santarosae at $\sim 13$ ka (Pinter and Anderson, 2006). They also appear to be synchronous with a peak in the charcoal/pollen ratio in the SBB ODP Site 893 interpreted independently as a regional biomass burning event including the adjacent mainland (Heusser and Sirocko, 1997). The distinctive dark layer at AC-003 in Arlington Canyon also correlates in time with other dark sedimentary layers distributed widely in North America marking the Ållerød-YD boundary (Haynes, 2008). Wildfire indicators (e.g., soot, glass-like carbon, and carbon spherules) occur in this layer with other exotic materials (e.g., magnetic spheres; Firestone et al., 2007; Haynes, 2008). This is consistent with the hypothesis that wildfires in southern California and elsewhere on the continent were ignited by an intense radiation flux associated with multiple airbursts resulting from a cosmic impact (Firestone et al., 2007). Hemispheric wildfires also increase abruptly at the beginning of the YD (Mayewski et al., 1993, 1997). The synchrony and geographic extent for wildfire in North America at 13-12.9 ka is inconsistent with human-induced fire, the growing evidence for Pre-Clovis occupations of the continent (Gilbert et al., 2008; Goebel et al., 2008), and the abrupt extinction of Mammuthus and additional Pleistocene animals. Based on current evidence, we argue that the synchronous and abrupt nature of wildfire and Pleistocene animal extinction on Santarosae and more broadly in North America are more consistent with the YDB cosmic impact hypothesis (Firestone et al., 2007) than any other hypotheses explaining Late Pleistocene megafauna extinctions.

\section{Acknowledgements}

This work was supported, in part, by US Department of Energy contract (DE-AC02-05CH11231), National Science Foundation (grants 99866999, OCD-0244201, ATM-0713769, GRFP-2006022778 and SBR-9521974), University of California, Santa Barbara (Office of Research [Michael Witherall] and Senate Research Grant), University of Oregon (College of Arts and Sciences and Office of Research) and the Santa Cruz Island Foundation. Fieldwork was conducted in Channel Islands National Park (CINP) with a research and collecting permit from the Department of the Interior (OMB\#1024-0236). Don Morris assisted us with the fieldwork and CINP logistics. We thank Anne Huston, Kelly Minas, Don Morris and the entire staff at CINP for their general support and assistance. We also thank the donors and volunteers at Santa Barbara Museum of Natural History. A final thanks to Jake Bartruff, John Donovan, Jennifer Donovan, Linda Heusser, Sarah McClure, John Southon, Carley Smith, Karen Thompson, and Megan Walsh, for their comments and assistance on various aspects of this work and to Rusty Van Rossman for the illustrations in Fig. 4. This paper was written with fellowship support from the AHRC Centre for the Evolution of Cultural Diversity, Institute of Archaeology, University College London and the Swiss Federal Institute of Technology Zurich (both to DJK).

\section{References}

Agenbroad, L.D., 1998. New pygmy mammoth (Mammuthus exilis) localities and radiocarbon dates from San Miguel, Santa Rosa, and Santa Cruz Islands, California. In: Weigand, P.W. (Ed.), Contributions to the Geology of the Northern Channel Islands Southern California. American Association of Petroleum Geologists, Pacific Section, Bakersfield, CA, pp. 169-176.

Agenbroad, L.D. 2002a. California's Channel Islands: a one-way trip in the tunnel of doom. In: Browne, D.R., Mitchell, K.L., Chaney, H.W. (Eds.), Proceedings of the Fifth California Islands Symposium. Santa Barbara Museum of Natural History, Santa Barbara, pp. 541-545.

Agenbroad, L.D., 2002b. New localities, chronology, and comparisons for the pygmy mammoth (Mammuthus exilis): 1994-1998. In: Browne, D.R., Mitchell, K.L., Chaney, H.W. (Eds.), Proceedings of the Fifth California Islands Symposium. Santa Barbara Museum of Natural History, Santa Barbara, pp. 518-524.

Agenbroad, L.D., Johnson, J.R., Morris, D., Stafford Jr., T.W., 2005. Mammoths and humans as Late Pleistocene contemporaries on Santa Rosa Island. In: Garcelon, D.K., Schwemm, C.A. (Eds.), Proceedings of the Sixth California Islands Symposium. Institute for Wildlife Studies, Arcata, CA, pp. 3-7.

Allen, B.D., Anderson, R.Y., 1993. Evidence from western North America for rapid shits in climate during the last glacial maximum. Science 260, 1920-1922.

Alvarez, L.W., Alvarez, W., Asaro, F., Michel, H.V., 1980. Extraterrestrial cause for the cretaceous-tertiary extinction. Science 208, 1095-1108.

Anderson, A., 1989. Mechanics of overkill in the extinction of New Zealand Moas. Journal of Archaeological Research 16, 137-151.

Anderson, D.G., Faught, M.K., 2000. Palaeoindian artefact distributions: evidence and implications. Antiquity $74,513-518$.

Anderson, K.M., 2005. Tending the Wild: Native American Knowledge and the Management of California's Natural Resources. University of California Press, Berkeley, CA.

Anderson, R.S., 2002. Fire and Vegetation History of Santa Rosa Island, Channel Islands National Park, California. Final report for a cooperative agreement (1443CA8000-8-0002) between Channel Islands National Park and Northern Arizona University. Channel Islands National Park, Ventura, CA

Bard, E., Hamelin, B., Arnold, M., Montaggioni, L., Cabioch, G., Faure, G., Rougerie, F., 1996. Deglacial sea-level record from Tahiti corals and the timing of global meltwater discharge. Nature 382, 241-244.

Bard, E., Hamelin, B., Fairbanks, R.G., 1990. U-Th ages obtained by mass-spectrometry in corals from Barbados - sea-level during the past 130,000 years. Nature 346, 456-458.

Barnosky, A.D., Koch, P.L., Feranec, R.S., Wing, S.L., Shabel, A.B., 2004. Assessing the causes of Late Pleistocene extinctions on the continents. Science 306, 70-75.

Bartlein, P.J., Edwards, M.E., Shafer, S.L., Barker Jr., E.D., 1995. Calibration of radiocarbon ages and the interpretation of paleoenvironmental records. Quaternary Research 44, 417-424. 
Behl, R.J., Kennett, J.P., 1996. Brief interstadial events in the Santa Barbara basin, NE Pacific, during the past 60 kyr. Nature 379, 243-246.

Benson, L., White, L.D., Rye, R., 1996. Carbonate deposition, Pyramid Lake subbasin, Nevada: 4. Comparison of the stable isotope values of carbon values of carbonate deposits (tufas) and the Lahontan lake-level record. Palaeogeography, Palaeoclimatology, Palaeoecology 122, 45-76.

Berger, R., 1980. Early man on Santa Rosa Island. In: Power, D.M. (Ed.), The California Islands: Proceedings of a Multidisciplinary Symposium. Santa Barbara Museum of Natural History, Santa Barbara, CA, pp. 73-78.

Berger, R., 1982. The Wooley mammoth site, Santa Rosa Island, California In: Ericson, J.E., Taylor, R.E., Berger, R. (Eds.), Peopling of the New World. Anthropological Papers 23. Ballena Press, pp. 163-170.

Berger, R., Orr, P., 1966. Early Man on Santa Rosa Island, California, II. Proceedings of the National Academy of Sciences 56, 1678-1682.

Bieling, D.G., La Jeunesse, R.M., Pryor, J.H., 1996. Skyrocket: a Central Sierran Paleoindian Archaic Transition Site. Current Research in the Pleistocene 13, 4-6.

Broecker, W.S., 1994. Massive iceberg discharges as triggers for global climate change. Nature 372, 421-424.

Broecker, W.S., 2006. Was the Younger Dryas triggered by a flood? Science 312, 1146-1148.

Bronk Ramsey, C., 1995. Radiocarbon calibration and analysis of stratigraphy: the OxCal program. Radiocarbon 37, 425-430.

Bronk Ramsey, C., 2001. Development of the radiocarbon calibration program OxCal. Radiocarbon 43 (2A), 355-363.

Buchanan, B., Collard, M., Edinborough, K., 2008. Paleoindian demography and the extraterrestrial impact hypothesis. Proceedings of the National Academy of Sciences 105, 11651-11654.

Burney, D.A., 1993. Late Holocene environmental changes in arid Southwestern Madagascar. Quaternary Research 40, 98-106.

Burney, D.A., Robinson, G.S., Burney, L.P., 2003. Sporormiella and the late Holocene extinctions in Madagascar. Proceedings of the National Academy of Sciences 100, 10800-10805.

Cannariato, K.G., Kennett, J.P., Behl, R.J., 1999. Biotic response to Late Quaternary rapid climate switches in Santa Barbara Basin: ecological and evolutionary implications. Geology 27, 63-66.

Chaney, R.H., Mason, H.L., 1930. A Pleistocene flora from Santa Cruz Islands. California. Carnegie Institution of Washington Publication 415, 1-24.

Coltrain, J.B., Harris, J.M., Cerling, T.E., Ehleringer, J.R., Dearing, M.-D., Ward, J., Allen, J., 2004. Rancho La Brea stable isotope biogeochemistry and its implications for the paleoecology of late Pleistocene, coastal southern California. Palaeogeography, Palaeoclimatology, and Palaeoecology 205, 199-219.

Dillehay, T.D. (Ed.), 1989. Monte Verde, a Late Pleistocene Settlement in Chile. Paleoenvironment and Site Context, vol. I. Smithsonian Institution Press, Washington.

Dillehay, T.D. (Ed.), 1997. Monte Verde, a Late Pleistocene Settlement in Chile. The Archaeological Context and Interpretation, vol. II. Smithsonian Institution Press, Washington.

Dillon, B.D., 2002. California Paleoindians: lack of evidence, or evidence of lack? In: Wallace, W.J., Riddell, F.A. (Eds.), Essays in California Archaeology: a Memorial to Franklin Fenenga. Contributions of the University of California Archaeological Research Facility no. 60, pp. 110-128.

Drummond, A.J., Rambaut, A., Shapiro, B., Pybus, O.G., 2005. Bayesian coalescent inference of past population dynamics from molecular sequences. Molecular Biology and Evolution 22, 1185-1192.

Erlandson, J.M., 2007. Sea change: the Paleocoastal occupations of Daisy Cave. In: Neusius, S.W., Gross, G.T. (Eds.), Seeking our Past: an Introduction to North American Archaeology. Oxford University Press, Oxford, pp. 135-143.

Erlandson, J.M., Rick, T.C., 2002. A 9700 year old shell midden on San Miguel Island, California. Antiquity 292, 315-316.

Erlandson, J.M., Rick, T.C., Jones, T.L., Porcasi, J.F., 2007. One if by Land, Two if by Sea: Who were the First Californians? In: Jones, T.L., Klar, K.A. (Eds.), California Prehistory: Colonization, Culture, and Complexity. Alta Mira Press, New York.

Erlandson, J.M., Kennett, D.J., Ingram, B.L., Guthrie, D.A., Morris, D.P., Tveskov, M.A., West, G.J., Walker, P.L., 1996. An Archaeological and Paleontological Chronology for Daisy Cave (CA-SMI-261), San Miguel Island, CA. Radiocarbon 38 355-373.

Erlandson, J.M., Rick, T.C., Vellanoweth, R.L., Kennett, D.J., 1999. Marine subsistence at a 9300 year old shell midden on Santa Rosa Island, California. Journal of Field Archaeology 26, 255-265.

Erlandson, J.M., Rick, T.C., Largaespada, T.L., Vellanoweth, R.L., 2004. CA-SMI-548: a 9500 year old shell midden at Running Springs, San Miguel Island, California. In: Bertrando, E., Levulett, V. (Eds.), Emerging from the ice age: early Holocene occupations on the Central California Coast. San Luis Obispo County Archaeological Society Occasional Papers 17, pp. 81-92.

Erlandson, J.M., Braje, T.J., Rick, T.C., Peterson, J.E., 2005. Beads, bifaces, and boats: An Early Holocene adaptation on the south coast of San Miguel Island, California. American Anthropologist 107, 677-683.

Erlandson, J.M., Moss, M.L., Des Lauriers, M., Living on the edge: early maritime cultures of the pacific coast of North America. Quaternary Science Reviews, in press.

Fairbanks, R.G., 1989. A 17,000 year glacio-eustatic sea level record: influence of glacial melting rates on the Younger Dryas event and deep-ocean circulation. Nature 342, 637-641.

Fergusson, G.J., Libby, W.F., 1964. UCLA radiocarbon dates, III. Radiocarbon 6, $318-339$.
Fisler, J., Hendy, I.L., 2008. California current system response to late Holocene climate cooling in southern California. Geophysical Research Letters 35 (9) L09702, doi:10.1029/2008GL033902.

Firestone, R.B., West, A., Kennett, J.P., Becker, L., Bunch, T.E., Revay, Z.S., Schultz, P.H. Belgya, T., Kennett, D.J., Erlandson, J.M., Dickenson, O.J., Goodyear, A.A Harris, R.S., Howard, G.A. Kloosterman, J.B., Lechler, P. Mayewski, P.A Montgomery, J., Poreda, R., Darrah, T., Que Hee, S.S., Smith, A.R., Stich, A. Topping, W., Wittke, J.H., Wolbach, W.S., 2007. Evidence for an extraterrestrial impact 12,900 years ago that contributed to the megafaunal extinctions and Younger Dryas cooling. Proceedings of the National Academy of Sciences 104, 16016-16021.

Gilbert, M.T.P., Jenkins, D.L., Götherstrom, A., Naveran, N., Sanchez, J.J., Hofreiter, M. Thomsen, P.F., Binladen, J., Higham, T.F.G., Yohe II, R.M., Parr, R. Cummings, L.S. Willerslev, E., 2008. DNA from pre-Clovis human coprolites in Oregon, North America. Science, doi:10.1126/science.1154116.

Goebel, T., Waters, M.R., O'Rourke, D.H., 2008. The Late Pleistocene dispersal of modern humans in the Americas. Science 319, 1497-1502.

Graham, N.E., Hughes, M.K., Ammann, C.M., Cobb, K.M., Hoerling, M.P., Kennett, D.J., Kennett, J.P., Rein, B., Stott, L., Wigand, P.E., Xu, T., 2007. Tropical pacificmid-latitude teleconnections in medieval times. Climate Change, vol. 83, pp. 241-285.

Grayson, D.K., 2007. Deciphering North American Pleistocene Extinctions. Journal of Anthropological Research 63, 185-213.

Grayson, D.K., Meltzer, D., 2002. Clovis hunting and large mammal extinction: a critical review of the evidence. Journal of World Prehistory 16, 313-359.

Hanebuth, T., Stattegger, K., Grootes, P.M., 2000. Rapid flooding of the Sunda Shelf: a late-glacial sea-level record. Science 288, 1033-1035.

Haug, G.H., Hughen, K.A., Peterson, L.C., Sigman, D.M., Röhl, U., 2001. Southward migration of the intertropical convergence zone through the Holocene. Science 293, 1304-1308.

Haynes Jr., C.V., 2005. Clovis, pre-Clovis, climate change, and extinction. In: Bonnichsen, R., Lepper, B.T., Stanford, D., Waters, M.R. (Eds.), Paleoamerican Origin: Beyond Clovis. Center for the Study of the First Americans, Department of Anthropology, Texas A\&M, College Station, TX.

Haynes Jr., C.V., 2007. Appendix B: nature and origin of the black mat, stratum $F_{2}$. In: Haynes Jr., C.V., Huckell, B.B. (Eds.), Murray Springs: a Clovis Site with Multiple Activity Areas in the San Pedro Valley, Arizona. University of Arizona Press, Tucson, AZ, pp. 240-249.

Haynes Jr., C.V., 2008. Younger Dryas “Black Mats" and the Rancholabrean termination in North America. Proceedings of the National Academy of Sciences 105, 6520-6525.

Hendy, I.L., Kennett, J.P., 1999. Latest Quaternary North Pacific surface-water responses imply atmosphere-driven climate instability. Geology 27, 291-294.

Hendy, I.L., Kennett, J.P., Roark, E.B., Ingram, B.L., 2002. Apparent synchroneity of submillennial scale climate events between Greenland and Santa Barbara Basin, California from 30-10 ka. Quaternary Science Reviews 21, 1167-1184.

Hendy, I.L., Pedersen, T.F., Kennett, J.P., Tada, R., 2004. Intermittent existence of southern California upwelling cell during submillennial climate change of the last 60 kyr. Paleoceanography 19, 1-15.

Heusser, L., 1995. Pollen stratigraphy and paleoecologic interpretation of the last 160 kyr from Santa Barbara, Ocean Drilling Project Hole 893A. In: Kennett, J.P. Baldauf, J.G., Lyle, M. (Eds.), Proceedings of the Ocean Drilling Program, Scientific Results. Ocean Drilling Program, College Station, TX, pp. 265-279.

Heusser, L., 1998. Direct correlation of millennial-scale changes in western North America vegetation and climate with changes in the California Current system over the past $\sim 60$ kyr. Paleoceanography 13, 252-262.

Heusser, L.E., Sirocko, F., 1997. Millennial pulsing of environmental change in southern California from the past 24 k.y.: a record of Indo-Pacific ENSO events? Geology 25, 243-246.

Holiday, V.T., 1985. Archaeological geology of the Lubbock Lake Site, Southern High Plains of Texas. Geological Society of America Bulletin 96, 1483-1492.

Hughen, K.A., Baillie, M.G.L., Bard, E., Beck, J.W., Bertrand, C.J.H., Blackwell, P.G., Buck, C.E., Burr, G.S., Cutler, K.B., Damon, P.E., Edwards, R.L., Fairbanks, R.G., Friedrich, M., Guilderson, T.P., Kromer, B., McCormac, G., Manning, S. Ramsey, C.B., Reimer, P.J., Reimer, R.W., Remmele, S., Southon, J.R., Stuiver, M. Talamo, S., Taylor, F.W., van der Plicht, J., Weyhenmeyer, C.E., 2004. Marine04 marine radiocarbon age calibration, 0-26 cal kyr BP. Radiocarbon 46, 1059 1086 .

Ingram, B.L., Southon, J.R., 1996. Reservoir ages in eastern Pacific coastal and estuarine waters. Radiocarbon $38,573-582$

Johnson, D.L., 1972. Landscape Evolution on San Miguel Island, California, Unpublished Ph.D. dissertation, University of Kansas.

Johnson, D.L., 1977. The Late Quaternary climate of coastal California: evidence for an ice age refugium. Quaternary Research 8, 154-179.

Johnson, J.R., Stafford Jr., T.W., Ajie, H.O., Morris, D.P., 2002. Arlington Springs revisited. In: Browne, D.R., Mitchell, K.L., Chaney, H.W. (Eds.), Proceedings of the Fifth California Islands Symposium. Santa Barbara Museum of Natural History, Santa Barbara, pp. 541-545.

Johnson, J.R., Stafford, T.W., Jr., West, G.J., Rockwell, T.K., 2007. Before and after the Younger Dryas: Chronostratigraphic and Paleoenvironmental research at Arlington Springs, Santa Rosa Island, California. American Geophysical Union Joint Assembly, Acapulco, 22 to 25 May 2007, Eos 88(23), Joint Assembly Supplement Abstr. PP 42A-03.

Jones, T.L., 2007. The Pleistocene-Holocene unconformity in California Prehistory American Geophysical Union Joint Assembly, Acapulco, 22 to 25 May 2007, Eos 88(23), Joint Assembly Supplement Abstr. PP 42A-07. 
Jones, T.L., Fitzgerald, R.T., Kennett, D.J., Misicek, C., Fagan, J., Sharp, J., Erlandson, J.E., 2002. The Cross Creek Site and its implications for New World Colonization. American Antiquity 67, 213-230.

Junger, S.T., Johnson, D.L., 1980. Was there a Quaternary land bridge to the Northern Channel Islands? In: Power, D.M. (Ed.), The California Islands: Proceedings of a Multidisciplinary Symposium. Santa Barbara Natural History Museum, Santa Barbara, CA, pp. 33-40.

Kennett, D.J., 2005. The Island Chumash: Behavioral Ecology of a Maritime Society University of California Press, Berkeley.

Kennett, D.J., Kennett, J.P., 2000. Competitive and cooperative responses to climatic instability in coastal southern California. American Antiquity 65, 379-395.

Kennett, D.J., Ingram, B.L., Southon, J.R., Wise, K., 2002. Differences in ${ }^{14} \mathrm{C}$ age between stratigraphically associated charcoal and marine shell from the archaic period site of kilometer 4, Southern Peru: old wood or old water? Radiocarbon 44, 53-58.

Kennett, D.J., Anderson, A., Prebble, M., Conte, E., Southon, J., 2006a. Human impacts on Rapa, French Polynesia. Antiquity 80, 340-354.

Kennett, D.J., Voorhies, B., Martorana, D., 2006b. An evolutionary model for the origins of agriculture on the pacific coast of Southern Mexico. In: Kennett, D.J., Winterhalder, B. (Eds.), Behavioral Ecology and the Transition to Agriculture. University of California Press, Berkeley, CA, pp. 103-136.

Kennett, D.J., Kennett, J.P., Erlandson, J.M., Cannariato, K.G., 2007. Human responses to middle Holocene climate change on California's Channel Islands. Quaternary Science Reviews 26, 351-367.

Kennett, D.J., Ingram, B.L., Erlandson, J.M., Walker, P., 1997. Evidence for tempora fluctuations in marine radiocarbon reservoir ages in the Santa Barbara Channel, Southern California. Journal of Archaeological Science 24, 1051-1059.

Kennett, J.P., Ingram, B.L., 1995a. Paleoclimatic evolution of Santa Barbara basin during the last 20 k.y.: marine evidence from hole 893A. In: Kennett, J.P. (Ed.) Proceedings of the Ocean Drilling Program, Scientific Results, vol. 146. Ocean Drilling Program, College Station, TX, pp. 309-325.

Kennett, J.P., Ingram, B.L., 1995b. A 20,000 year record of ocean circulation and climate change from the Santa Barbara basin. Nature 377, 510-514.

Kennett, J.P., Baldauf, J.G., Lyle, M. (Eds.), 1995, Proceedings of the Ocean Drilling Program, Scientific Results, vol. 146. Ocean Drilling Program, College Station, TX

Kinlan, B.P., Graham, M.H., Erlandson, J.M., 2005. Late Quaternary changes in the size shape, and isolation of the California Islands: ecological and anthropological implications. In: Garcelon, D.K., Schwemm, C.A. (Eds.), Proceedings of the Sixth California Islands Symposium. Institute of Wildlife Studies, Arcata, CA, pp. 131-142.

Köeberl, C., 2007. The geochemistry and cosmochemistry of impacts. In: Davis, A (Ed.), Treatise on Geochemistry, vol. 1. Elsevier, pp. 1-52.

Longo, G., Serra, R., Cecchina, S., Galli, M., 1994. Search for microremnants of the Tunguska Cosmic Body. Planetary and Space Science 42, 163-177.

Marcus, L.F., Berger, R., 1984. The significance of radiocarbon dates for Rancho La Brea. In: Martin, P.S., Klein, R.G. (Eds.), Quaternary Extinctions: a Prehistoric Revolution. University of Arizona Press, Tucson, AZ, pp. 159-183.

Martin, P.S., 1967. Prehistoric overkills. In: Martin, P.S., Wright, H.E. (Eds.), Pleistocene Extinctions: the Search for a Cause. Yale University Press, New Haven, pp. 75-120.

Martin, P.S., 2005. Twilight of the Mammoths: Ice Age Extinctions and the Rewilding of America. University of California Press, Berkeley.

Meighan, C., Haynes, C.V., 1970. The Borax Lake Site revisited. Science 167, 1213-1221.

Mayewski, P.A., Meeker, L.D., Whitlow, S.I., Winckler, M.S., Morrison, M.G. Alley, R.B., Bloomfield, P., Taylor, K., 1993. The atmosphere during the Younge Dryas. Science 261, 195-197.

Mayewski, P.A., Meeker, L.D., Twickler, M.S., Whitlow, S.I., Yang, Q., Lyons, W.B. Prentice, M., 1997. Major features and forcing of high-latitude northern hemisphere atmospheric circulation using a 110,000-year-long glaciochemical series. Journal of Geophysical Research 102, 26345-26366.

McDonald, J.N., 1981. North American Bison: their Classification and Evolution. University of California Press, Berkeley, CA.

Muscheler, R., Kromer, B., Björck, S., Svensson, A., Friedrch, M., Kaiser, K.F., Southon, J., 2008. Tree rings and ice cores reveal ${ }^{14} \mathrm{C}$ calibration uncertainties during the Younger Dryas. Nature doi:10.1038/ngeo128.

Nederbragt, A.J., Thurow, J., 2005. Geographic coherence of millennial-scale climate cycles during the Holocene. Palaeogeography, Palaeoclimatology, Palaeoecology $221,313-324$.

Nederbragt, A.J., Thurow, J.W., Bown, P.R., 2008. Paleoproductivity, ventilation, and organic carbon burial in the Santa Barbara Basin (ODP Site 893, off California) since the last glacial. Paleoceanography 23, 1-15.

Orr, P.C., 1968. Prehistory of Santa Rosa Island. Santa Barbara Museum of Natura History, CA.

Orr, P.C., Berger, R., 1966. The fire areas on Santa Rosa Island, California. Proceedings of the National Academy of Sciences 56, 1409-1416.

Ortiz, J.D., Mix, A.C., Rugh, W., Watkins, J.M., Collier, R.W., 1996. Deep-dwelling planktonic foraminifera of the northeastern Pacific Ocean reveal environmenta control of oxygen and carbon isotopic disequilibria. Geochimica et Cosmochimica Acta 60, 4509-4523.

Patton, M., 1996. Islands in Time: Island Sociogeography and Mediterranean Prehistory. Routledge, New York.

Pettitt, P.B., Davies, W., Gamble, C.S., Richards, M.B., 2003. Paleolithic radiocarbon chronology: quantifying our confidence beyond two half-lives. Journal of Archaeological Science 30, 1685-1693.
Pinter, N., Johns, B., Little, B., Vestal, W.D., 2001. Fault-related folding in California's Northern Channel Islands documented by rapid-static GPS positioning. GSA Today 11, 4-9.

Pinter, N., Sorlien, C.C., Scott, A.T., 2003. Fault-related fold growth and isostatic subsidence, California Channel Islands. American Journal of Science 303, 300-318.

Pinter, N., Anderson, S., 2006. A mega-fire hypothesis for the latest Pleistocene Paleo-environmental change on the Northern Channel Islands, California. Abstracts with Programs. Geological Society of America Vol. 38, no (7) Paper No. 66-13.

Piperno, D.R., Bush, M.B., Colinvaux, P.A., 1991. Paleoecological perspectives on human adaptation in Central Panama. II The Holocene. Geoarchaeology 6, 227-250.

Porcasi, P., Porcasi, J.F., O'Neill, C., 1999. Early Holocene coastlines of the California Bight: the Channel Islands as first visited by humans. Pacific Coast Archaeological Society Quarterly 35,1-24.

Posey, D., 1985. Indigenous management of tropical forest ecosystems: the Kayopo Indians of the Brazilian Amazon. Agroforestry Systems 3, 139-158.

Pospelova, V., Pedersen, T.F., de Vernal, A., 2006. Dinoflagellate cysts as indicators of climatic and oceanographic changes during the past $40 \mathrm{kyr}$ in the Santa Barbara Basin, southern California. Paleoceanography 21.

Quade, J., Forester, R.M., Pratt, W.L., Carter, C., 1998. Black mats, spring-fed streams, and late-glacial-age recharge in the Southern Great Basin. Quaternary Research 49, 129-148.

Reimer, P.J., Baillie, M.G.L., Bard, E., Bayliss, A., Beck, J.W., Bertrand, C., Blackwell, Buck, C.E., Burr, G., Cutler, K.B., Damon, P.E., Edwards, R.L., Fairbanks, R.G., Friedrich, M., Guilderson, T.P., Hughen, K.A., Kromer, B., McCormac, F.G., Manning, S., Bronk Ramsey, C., Reimer, R.W., Remmele, S., Southon, J.R., Stuiver, M., Talamo, S., Taylor, F.W., van der Plicht, J., Weyhenmeyer, C.E., 2004 IntCal04 Terrestrial radiocarbon age calibration, 26-0 ka BP. Radiocarbon 46, 1029-1058.

Rick, T.C., Erlandson, J.M., Vellanoweth, R.L., 2001. Paleocoastal marine fishing on the Pacific coast of the Americas: perspectives from Daisy Cave, California. American Antiquity 66, 595-613.

Rick, T.C., Erlandson, J.M., Vellanoweth, R.L., Braje, T.J., 2005. From Pleistocene mariners to complex hunter-gatherers: the archaeology of the California Channel Islands. Journal of World Prehistory 19, 169-228.

Roark, E.B., Ingram, B.L., Southon, J., Kennett, J.P., 2003. Holocene foraminiferal radiocarbon record of paleocirculation in the Santa Barbara Basin. Geology 31, 379-382.

Rondeau, M., Cassidy, J., Jones, T.L., 2007. Colonization Technologies: Fluted Projectile Points and the San Clemente Island woodworking/microblade complex. In: Jones, T.L., Klar, K.A. (Eds.), California Prehistory: Colonization, Culture, and Complexity. Altamira Press, Walnut Creek, California.

Sarnthein, M., Grootes, P., Kennett, J.P., Nadeau, M.J., 2007. ${ }^{14} \mathrm{C}$ Reservoir ages show deglacial changes in ocean currents and carbon cycle. In: Schmittner, A., Chiang, J., Hemming, S. (Eds.), Ocean Circulation: Mechanisms and Impacts. AGU, pp. 175-196

Schiffer, M.B., 1986. Radiocarbon dating and the "old wood" problem: the case of the Hohokam chronology. Journal of Archaeological Science 13, 13-30.

Siddall, M., Rohling, E.J., Almogi-Labin, A., Hemleben, Ch., Meischner, D., Schmelzer, I., Smeed, D.A., 2003. Sea-level fluctuations during the last glacial cycle. Nature 423, 853-858.

Steadman, D.W., 1995. Prehistoric extinctions of Pacific island birds: biodiversity meets zooarchaeology. Science 267, 1123-1130.

Smith, B.B., 2001. Low level food production. Journal of Archaeological Research 9, $1-43$.

Sorlien, C.C., 1994. Faulting and uplift on the Northern Channel Islands, California. In: Halvorson, W.L., Maender, G.J. (Eds.), The Fourth Channel Islands Symposium: Update on the Status of Resources. Santa Barbara Museum of Natural History, Santa Barbara, CA, pp. 281-296.

Spriggs, M., 1989. The dating of the island Southeast Asian Neolithic: an attempt at chronometric hygiene and linguistic correlation. Antiquity 63, 587-613.

Stuiver, M., Grootes, P.M., 2000. GISP2 oxygen isotope ratios. Quaternary Research 53, 277-283.

Stuiver, M., Reimer, P.J., Reimer, R.W., 2004. CALIB 4.0. Available from: <www.calib. org $>$.

Taylor, R.E., Haynes Jr., C.V., Stuiver, M., 1996. Clovis and Folsom age estimates: stratigraphic context and radiocarbon calibration. Antiquity 70, 515-525.

Telford, R.J., Heegaard, E., Birks, H.J.B., 2004. The intercept is a poor estimate of a calibrated radiocarbon age. Holocene 14, 296-298.

Waters, M.R., Stafford Jr., T.W., 2007. Redefining the age of Clovis: implications for the peopling of the Americas. Science 315, 1122-1126.

West, G.J., 1994. A late Pleistocene pollen record from San Miguel Island, California: preliminary results. Abstracts with Program. AMQUA 13, 256.

Wolbach, W.S., Lewis, R.S., Anders, S., 1985. Cretaceous extinctions: evidence for wildfires and search for meteoritic impact. Science 230, 167-170.

Yancheva, G.N., Nowaczyk, R., Mingram, J., Dulski, P., Schettler, G., Negendank, J.F.W., Liu, J., Sigman, D.M., Peterson, L.C., Haug, G.H., 2007. Influence of the intertropical convergence zone on the East Asian monsoon. Nature 445, doi:10.1038/ nature05431.

Yen, D., 1989. The domestication of environment. In: Harris, D., Hillman, G. (Eds.), Foraging and Farming. Unwin Press, London, pp. 55-75. 